\title{
Epithelial junctions and attachments ${ }^{*}$
}

\author{
Michel Labouesse ${ }^{\S}$, Institut de Génétique et de Biologie Moléculaire et \\ Cellulaire CNRS/ INSERM/ULP, BP 10142, 67404 Illkirch Cedex France
}

\section{Table of Contents}

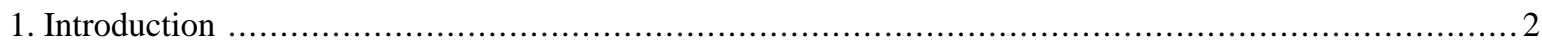

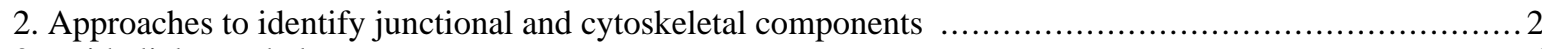

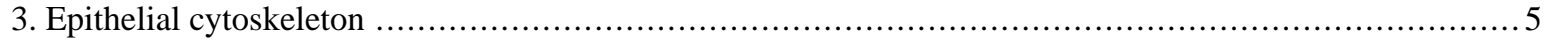

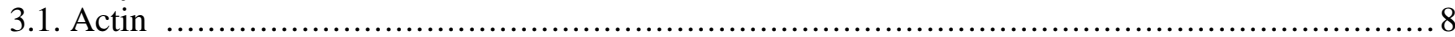

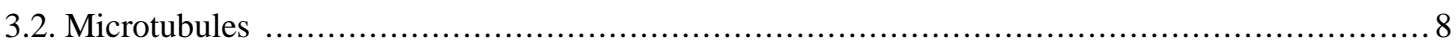

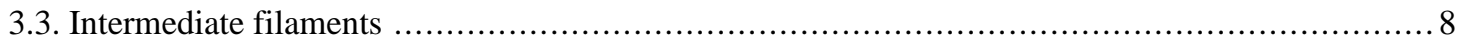



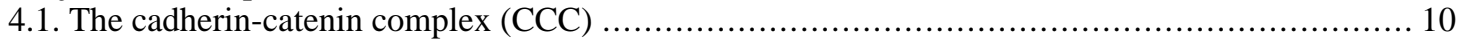

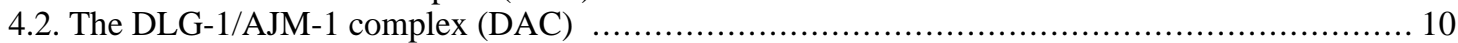

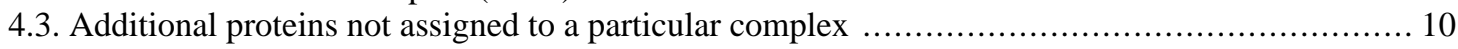

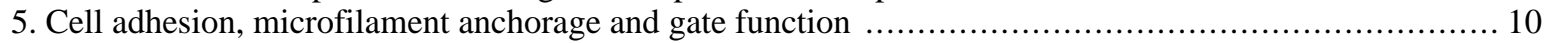

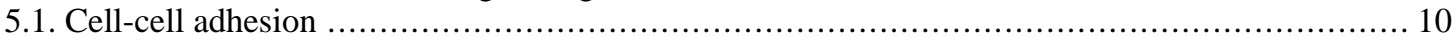

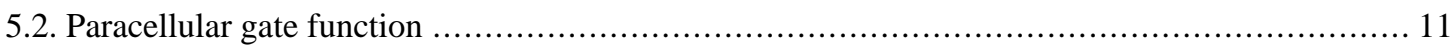

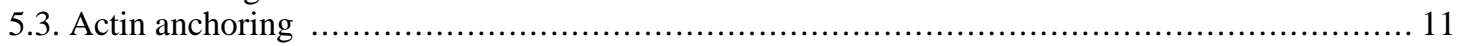

6. Assembly of apical junctions and establishment of epithelial polarity ...................................... 12

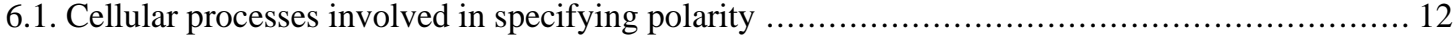



6.3. Apical proteins involved in specifying polarity and tubulogenesis ................................ 13



8. Fibrous organelles: junctions with the extracellular matrix and mechanical coupling …................... 14

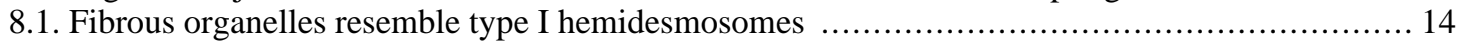

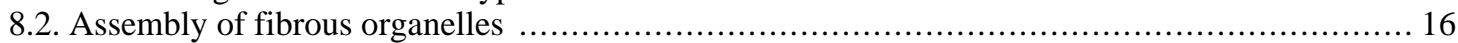



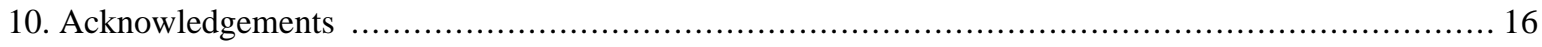

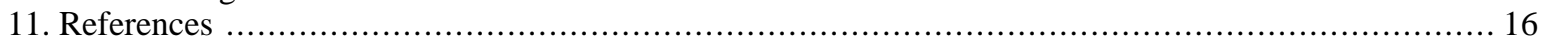

\section{Abstract}

A distinctive feature of polarized epithelial cells is their specialized junctions, which contribute to cell integrity and provide platforms to orchestrate cell shape changes. The chapter discusses the composition and assembly of $C$. elegans cell-cell and cell-extracellular matrix junctions, proteins that anchor the cytoskeleton

\footnotetext{
*Edited by James M. Kramer and Donald G. Moerman. Last revised January 29, 2005. Published January 13, 2006. This chapter should be cited as: Labouesse, M. Epithelial junctions and attachments (January 13, 2006), WormBook, ed. The C. elegans Research Community, WormBook, doi/10.1895/wormbook.1.56.1, http://www.wormbook.org.

Copyright: $\odot 2006$ Michel Labouesse. This is an open-access article distributed under the terms of the Creative Commons Attribution License, which permits unrestricted use, distribution, and reproduction in any medium, provided the original author and source are credited.

${ }^{\S}$ To whom correspondence should be addressed. E-mail: 1michel@igbmc.u-strasbg.fr
} 
and mechanisms involved in establishing epithelial polarity. The focus remains cellular and does not properly deal with epithelial cells in the context of the developing embryo.

\section{Introduction}

The interest in epithelial junctions and their associated cytoskeletal elements is recent. Essentially none of the genes mentioned in this chapter were known, let alone discussed, when $C$. elegans II was released. This chapter introduces the main players, and addresses cell adhesion, cytoskeletal anchoring, epithelial polarity and fibrous organelle assembly with a focus on cellular function. For developmental aspects or for a more comprehensive coverage of cell adhesion, the reader should consult the chapter on Epidermal morphogenesis and reviews (Cox et al., 2004; Ding et al., 2004).

\section{Approaches to identify junctional and cytoskeletal components}

The first reagents used to visualize junctional/cytoskeletal components were obtained approximately 20 years ago when Francis and Waterston prepared monoclonal antibodies (mAbs) against insoluble membrane-associated embryonic extracts (Francis and Waterston, 1985; Francis and Waterston, 1991). Some of these mAbs turned out to recognize junctional components (LET-805/myotactin, AJM-1, VAB-10, recognized by MH46, MH27 and MH5 mAbs, respectively) or intermediate filaments (IFs; MH4 and MH33 mAbs), and proved in some cases useful for cloning by means of phage display.

Since then, genes encoding junctional or cytoskeletal components have been identified in screens for larval defects (sma-1, mua-3, mua-6, vab-10), elongation defects causing embryonic lethality (hmr-1, hmp-1, hmp-2, spc-1, zen-4, mup-4, pat- genes), or variably penetrant sub-lethal body morphology defects (vab-10, ifb-1, vab-19). Chromosomal deficiencies have also been used to scan the genome for regions containing loci potentially required for embryonic morphogenesis (let-413,vab-10). With some exceptions (let-805/myotactin, ajm-1), all genes identified through these screens turned out to encode proteins with clear homologues in vertebrates and insects (see Table 1, Figure 2).

Several junction and cytoskeleton components have also been identified in diverse RNAi screens, a number that should increase. Table 1 is a list of junctional/cytoskeletal proteins, that is unlikely to be complete. A promising source for additional adhesion proteins will be to mine the C. elegans genome (Hutter et al., 2000).

Table 1. Genes are grouped (different shadings) according to their subcellular localization and/or function (see also Figure 2).

\begin{tabular}{|c|c|c|c|c|c|c|}
\hline Gene & $\begin{array}{l}\text { Homology or } \\
\text { (domains) }\end{array}$ & $\begin{array}{l}\text { Expression } \\
\text { pattern }\end{array}$ & $\begin{array}{l}\text { Subcellular } \\
\text { localization }\end{array}$ & Phenotype & $\begin{array}{l}\text { Identification } \\
\text { method }\end{array}$ & Reference \\
\hline act-5 & Actin & Int. & Apical & $\begin{array}{l}\text { Larval let; gut } \\
\text { lumen def. }\end{array}$ & RNAi & Gobel et al., 2004 \\
\hline erm-1 & $\begin{array}{l}\text { Ezrin-radixin- } \\
\text { moesin (FERM } \\
\text { domain) }\end{array}$ & Most epithelia & Apical & $\begin{array}{l}\text { Larval let; gut } \\
\text { consctriction }\end{array}$ & RNAi & $\begin{array}{l}\text { Gobel et al., 2004; } \\
\text { Van Furden et al., } \\
2004\end{array}$ \\
\hline eps-8 & $\begin{array}{l}\text { EPS8 (PTB, } \\
\text { SH3) }\end{array}$ & $\begin{array}{l}\text { Int. (also many } \\
\text { other cells) }\end{array}$ & $\begin{array}{l}\text { Tip of int. } \\
\text { microvilli, PM } \\
\text { in embryos }\end{array}$ & $\begin{array}{l}\text { Emb; larval let; } \\
\text { ab. Int.brush } \\
\text { border }\end{array}$ & Homol. + del & Croce et al., 2004 \\
\hline sma-1 & $\beta_{\mathrm{H}}$-spectrin & $\begin{array}{l}\text { Ep., int., P., } \\
\text { E.c. }\end{array}$ & Apical & Elongation def. & Larval def. & $\begin{array}{l}\text { McKeown et al., } \\
\text { 1998; Norman and } \\
\text { Moerman, } 2002\end{array}$ \\
\hline$s p c-1$ & $\alpha$-spectrin & Ubiq. & $\begin{array}{l}\text { Apical, } \\
\text { basolateral }\end{array}$ & $\begin{array}{l}\text { Emb; } \\
\text { elongation def. }\end{array}$ & $\mathrm{Emb}$ & $\begin{array}{l}\text { Moorthy et al., } \\
\text { 2000; Norman and } \\
\text { Moerman, } 2002\end{array}$ \\
\hline unc-70 & $\beta_{\mathrm{G}}$-spectrin & Ubiq. & Basolateral & Larval let & Larval def. & $\begin{array}{l}\text { Hammarlund et al., } \\
\text { 2000; Moorthy et } \\
\text { al., } 2000\end{array}$ \\
\hline
\end{tabular}




\begin{tabular}{|c|c|c|c|c|c|c|}
\hline Gene & $\begin{array}{l}\text { Homology or } \\
\text { (domains) }\end{array}$ & $\begin{array}{l}\text { Expression } \\
\text { pattern }\end{array}$ & $\begin{array}{l}\text { Subcellular } \\
\text { localization }\end{array}$ & Phenotype & $\begin{array}{l}\text { Identification } \\
\text { method }\end{array}$ & Reference \\
\hline$n f m-1$ & $\begin{array}{l}\text { Merlin (FERM } \\
\text { domain) }\end{array}$ & Int. & Basolateral & Unknown & RNAi & Gobel et al., 2004 \\
\hline$h m r-1$ & E-cadherin & Ep., int., $P$. & CeAJ & $\begin{array}{l}\text { Emb; ventral } \\
\text { enclosure def. }\end{array}$ & Emb & $\begin{array}{l}\text { Costa et al., 1998; } \\
\text { Raich et al., } 1999\end{array}$ \\
\hline$h m p-1$ & $\alpha$-catenin & Ep., int., $P$. & CeAJ & $\begin{array}{l}\text { Emb; } \\
\text { elongation def. }\end{array}$ & Emb & $\begin{array}{l}\text { Costa et al., 1998; } \\
\text { Pettitt et al., 2003; } \\
\text { Raich et al., 1999 }\end{array}$ \\
\hline$h m p-2$ & $\beta$-catenin & Ep., int., $P$. & CeAJ & $\begin{array}{l}\text { Emb; } \\
\text { elongation def. }\end{array}$ & Emb & $\begin{array}{l}\text { Costa et al., 1998; } \\
\text { Raich et al., } 1999\end{array}$ \\
\hline$j a c-1$ & P120-catenin & Ep., int., P. & CeAJ & None alone & RNAi & Pettitt et al., 2003 \\
\hline$v a b-9$ & $\begin{array}{l}\text { BCMP1 } \\
\text { claudin }\end{array}$ & Ep., int., P. & CeAJ & Elongation def. & Larval def. & Simske et al., 2003 \\
\hline apr-1 & APC & Ep., int., $P$. & CeAJ & $\begin{array}{l}\text { Emb; ventral } \\
\text { enclosure def. }\end{array}$ & m.b. & Hoier et al., 2000 \\
\hline$d \lg -1$ & $\begin{array}{l}\text { Discs Large } \\
\text { (PDZ, SH3, } \\
\text { GuK) }\end{array}$ & All epithelia & $\mathrm{CeAJ}$ & $\begin{array}{l}\text { Emb; } \\
\text { elongation def. }\end{array}$ & RNAi & $\begin{array}{l}\text { Bossinger et al., } \\
\text { 2001; Firestein and } \\
\text { Rongo, 2001; } \\
\text { Koppen et al., 2001; } \\
\text { McMahon et al., } \\
\text { 2001; Segbert et al., } \\
2004\end{array}$ \\
\hline ajm-1 & $\begin{array}{l}\text { Novel (coiled } \\
\text { coil) }\end{array}$ & All epithelia & CeAJ & \begin{tabular}{|l|} 
Emb; \\
elongation def.
\end{tabular} & mAb + e.s. & $\begin{array}{l}\text { Bossinger et al., } \\
\text { 2001; Koppen et al., } \\
\text { 2001; Priess and } \\
\text { Hirsh, } 1986\end{array}$ \\
\hline clc-1 & $\begin{array}{l}\text { Classical } \\
\text { claudin }\end{array}$ & $\mathrm{P}$. & $\mathrm{CeAJ}$ & $\begin{array}{l}\text { Permeability } \\
\text { def. }\end{array}$ & RNAi & Asano et al., 2003 \\
\hline $\begin{array}{l}\text { lad-1/ } \\
\text { sax-7 }\end{array}$ & $\begin{array}{l}\text { L1CAM (FN3 } \\
+ \text { Ig rep) }\end{array}$ & All epithelia & CeAJ & $\begin{array}{l}\text { Partial Emb; } \\
\text { elongation def. }\end{array}$ & $\begin{array}{l}\text { Larval screen; } \\
\text { Homol. + del }\end{array}$ & $\begin{array}{l}\text { Chen et al., 2001; } \\
\text { Sasakura et } \\
\text { al.,2005; Wang et } \\
\text { al., 2005 }\end{array}$ \\
\hline let-413 & $\begin{array}{l}\text { Scribble (LRR, } \\
\text { PDZ) }\end{array}$ & $\begin{array}{l}\text { Ubiq. up } \\
\text { 350-c, all } \\
\text { epithelia }\end{array}$ & Basolateral & $\begin{array}{l}\text { Emb; } \\
\text { elongation def. }\end{array}$ & Df screen & $\begin{array}{l}\text { Bossinger et al., } \\
\text { 2004; Legouis et al., } \\
\text { 2000; Legouis et al., } \\
2003\end{array}$ \\
\hline par-3 & PAR-3 (PDZ) & $\begin{array}{l}\text { Early embryo; } \\
\text { int., spermT. }\end{array}$ & Apical & $\begin{array}{l}\text { Emb; } \\
\text { gastrulation } \\
\text { def.; Ste }\end{array}$ & RNAi & $\begin{array}{l}\text { Aono et al., 2004; } \\
\text { Nance et al., 2003; } \\
\text { Nance and Priess, } \\
2002\end{array}$ \\
\hline par-6 & PAR-6 (PDZ) & $\begin{array}{l}\text { Early embryo; } \\
\text { int. }\end{array}$ & Apical & $\begin{array}{l}\text { Emb; } \\
\text { gastrulation } \\
\text { def. }\end{array}$ & RNAi & $\begin{array}{l}\text { Nance et al., 2003; } \\
\text { Nance and Priess, } \\
2002\end{array}$ \\
\hline$c r b-1$ & Crumbs & Int. & Apical & None alone & RNAi & $\begin{array}{l}\text { Bossinger et al., } \\
\text { 2001; Segbert et al., } \\
2004\end{array}$ \\
\hline$z e n-4$ & $\begin{array}{l}\text { MKLP1 } \\
\text { kinesin }\end{array}$ & $\begin{array}{l}\text { Unknown in } \\
\text { epithelia }\end{array}$ & Unknown & \begin{tabular}{|l} 
Emb; no \\
buccal cavity
\end{tabular} & Emb & $\begin{array}{l}\text { Mishima et al., } \\
\text { 2002; Portereiko et } \\
\text { al., 2004; Raich et } \\
\text { al., } 1998\end{array}$ \\
\hline$c y k-4$ & RhoGAP (PH, & Unknown in & Unknown & Emb; no & Emb & Jantsch- Plunger et \\
\hline
\end{tabular}




\begin{tabular}{|c|c|c|c|c|c|c|}
\hline Gene & \begin{tabular}{|l|l}
$\begin{array}{l}\text { Homology or } \\
\text { (domains) }\end{array}$ \\
\end{tabular} & $\begin{array}{l}\text { Expression } \\
\text { pattern }\end{array}$ & $\begin{array}{l}\text { Subcellular } \\
\text { localization }\end{array}$ & Phenotype & $\begin{array}{l}\text { Identification } \\
\text { method }\end{array}$ & Reference \\
\hline & GAP) & epithelia & & buccal cavity & & $\begin{array}{l}\text { al., 2000; Mishima } \\
\text { et al., 2002; } \\
\text { Portereiko et al., } \\
2004\end{array}$ \\
\hline ifa-1 & IF & $\begin{array}{l}\text { R., V. Ut., E.c., } \\
\text { P., P-I. v. }\end{array}$ & FO & Larval let & Bioch.; RNAi & $\begin{array}{l}\text { Dodemont et al., } \\
\text { 1994; Karabinos et } \\
\text { al., 2001; Karabinos } \\
\text { et al., } 2003\end{array}$ \\
\hline $\begin{array}{l}\text { mua-6/ } \\
\text { ifa-2 }\end{array}$ & IF & Ep., R., V. Ut., & FO & Muscle detach. & Larval def. & $\begin{array}{l}\text { Dodemont et al., } \\
\text { 1994; Hapiak et al., } \\
\text { 2003; Karabinos et } \\
\text { al., 2001; Karabinos } \\
\text { et al., 2003 }\end{array}$ \\
\hline ifa-3 & IF & Ep., R., P-I. v. & FO & $\begin{array}{l}\text { Emb; muscle } \\
\text { detach }\end{array}$ & Bioch.; RNAi & $\begin{array}{l}\text { Dodemont et al., } \\
\text { 1994; Karabinos et } \\
\text { al., 2001; Karabinos } \\
\text { et al., 2003; Woo et } \\
\text { al., } 2004\end{array}$ \\
\hline$i f b-1$ & IF & $\begin{array}{l}\text { Ep., R., V. Ut., } \\
\text { P., P-I. v. }\end{array}$ & FO & $\begin{array}{l}\text { Emb; muscle } \\
\text { detach }\end{array}$ & Vab / RNAi & $\begin{array}{l}\text { Dodemont et al., } \\
\text { 1994; Karabinos et } \\
\text { al., 2001; Karabinos } \\
\text { et al., 2003; Woo et } \\
\text { al., } 2004\end{array}$ \\
\hline ifc-1 & IF & Ep., R., P., int. & $\begin{array}{l}\text { FO in ep.?, } \\
\text { CeAJ in P., } \\
\text { apical in int. }\end{array}$ & Partial lethality & $\mathrm{mAb}+$ e.s. & $\begin{array}{l}\text { Karabinos et al., } \\
\text { 2001; Karabinos et } \\
\text { al., 2003; Karabinos } \\
\text { et al., } 2004\end{array}$ \\
\hline$i f_{c-2}$ & IF & P., int. & $\begin{array}{l}\text { Cytoplasmic + } \\
\text { CeAJ }\end{array}$ & $\begin{array}{l}\text { Weak lethality } \\
\text { in adults }\end{array}$ & $\mathrm{mAb}+$ e.s. & $\begin{array}{l}\text { Karabinos et al., } \\
\text { 2002; Karabinos et } \\
\text { al., } 2004\end{array}$ \\
\hline \begin{tabular}{|l} 
ifb-2, \\
ifd- 1, \\
ifd-2, ife- 1
\end{tabular} & IF & Int. & Apical & $\begin{array}{l}\text { None alone/ } \\
\text { partial larval } \\
\text { let in triple } \\
\text { knock-down }\end{array}$ & mAb + e.s. & $\begin{array}{l}\text { Bossinger et al., } \\
\text { 2004; Dodemont et } \\
\text { al., 1994; Karabinos } \\
\text { et al., 2001; } \\
\text { Karabinos et al., } \\
\text { 2003; Karabinos et } \\
\text { al., } 2004\end{array}$ \\
\hline let-805 & $\begin{array}{l}\text { Novel (FN3 } \\
\text { repeats + TM) }\end{array}$ & $\begin{array}{l}\text { Hyp syncytia, } \\
\text { P cells, P. }\end{array}$ & FO & $\begin{array}{l}\text { Emb; muscle } \\
\text { detach }\end{array}$ & $\mathrm{mAb}+$ e.s. & Hresko et al., 1999 \\
\hline mup-4 & $\begin{array}{l}\text { Matrilin-like } \\
\text { (VWA+EGF } \\
\text { rep.; TM) }\end{array}$ & $\begin{array}{l}\text { Hyp syncytia, } \\
\text { P cells, } \mathrm{P} \text {. }\end{array}$ & FO & $\begin{array}{l}\text { Emb; muscle } \\
\text { detach }\end{array}$ & Emb & $\begin{array}{l}\text { Gatewood and } \\
\text { Bucher, 1997; Hong } \\
\text { et al., 2001 }\end{array}$ \\
\hline mиа-3 & $\begin{array}{l}\text { Matrilin-like } \\
\text { (LDL+ VWA+ } \\
\text { EGF rep.; TM) }\end{array}$ & $\begin{array}{l}\text { Hyp syncytia, } \\
\text { P cells, P. }\end{array}$ & FO & Muscle detach & Larval def. & $\begin{array}{l}\text { Bercher et al., 2001; } \\
\text { Plenefisch et al., } \\
2000\end{array}$ \\
\hline$v a b-19$ & $\begin{array}{l}\text { Kank (ANK } \\
\text { rep.) }\end{array}$ & $\begin{array}{l}\text { Hyp syncytia, } \\
\mathrm{P} \text { cells, } \mathrm{P} \text {. }\end{array}$ & FO & $\begin{array}{l}\text { Emb; muscle } \\
\text { detach }\end{array}$ & Vab screen & Ding et al., 2003 \\
\hline$v a b-10 A$ & $\begin{array}{l}\text { Plakin }(\mathrm{CH} \\
\text { rep.; SPEC, } \\
\text { PLEC rep.) }\end{array}$ & $\begin{array}{l}\text { Hyp syncytia, } \\
\text { P cells, P. }\end{array}$ & FO & $\begin{array}{l}\text { Emb; muscle } \\
\text { detach }\end{array}$ & $\begin{array}{l}\text { Df \& larval } \\
\text { screens }\end{array}$ & $\begin{array}{l}\text { Bosher et al., 2003; } \\
\text { Plenefisch et al., } \\
2000\end{array}$ \\
\hline$v a b-10 B$ & Plakin $(\mathrm{CH}$ & Hyp syncytia, & Between FO in & Emb; ep. & Df \& larval & Bosher et al., 2003 \\
\hline
\end{tabular}




\begin{tabular}{|c|c|c|c|c|c|c|}
\hline Gene & $\begin{array}{l}\begin{array}{l}\text { Homology or } \\
\text { (domains) }\end{array} \\
\end{array}$ & $\begin{array}{l}\text { Expression } \\
\text { pattern }\end{array}$ & $\begin{array}{l}\text { Subcellular } \\
\text { localization }\end{array}$ & Phenotype & $\begin{array}{l}\text { Identification } \\
\text { method }\end{array}$ & Reference \\
\hline & $\begin{array}{l}\text { rep.; SPEC } \\
\text { rep.; GAR) }\end{array}$ & $\begin{array}{l}\text { P cells, P., R., } \\
\text { int., muscles, } \\
\text { NS }\end{array}$ & $\begin{array}{l}\text { ep. apical in } \\
\text { gut }\end{array}$ & thickening & screens & \\
\hline mel-11 & $\begin{array}{l}\text { MBP (ANK } \\
\text { rep.) }\end{array}$ & Epidermis & $\mathrm{CeAJ}$ & $\begin{array}{l}\text { Ste; enclosure } \\
\text { def. }\end{array}$ & Suppressor & $\begin{array}{l}\text { Piekny et al., 2003; } \\
\text { Wissmann et al., } \\
\text { 1999; Wissmann et } \\
\text { al., } 1997\end{array}$ \\
\hline$p t p-3$ & $\begin{array}{l}\text { Protein } \\
\text { phosphatase } \\
\text { (TM) }\end{array}$ & Epidermis & $\mathrm{CeAJ}$ & $\begin{array}{l}\text { Body } \\
\text { morphology } \\
\text { def. }\end{array}$ & Homol. + del & $\begin{array}{l}\text { Harrington et al., } \\
2002\end{array}$ \\
\hline$c d c-42$ & Cdc42 GTPase & Epidermis. & $\mathrm{CeAJ}$ & Unknown & Homol. & $\begin{array}{l}\text { Chen et al., 1996; } \\
\text { Chen et al., 1993; } \\
\text { Chen et al., 1993 }\end{array}$ \\
\hline \begin{tabular}{|l|} 
ced-10/ \\
rac-1
\end{tabular} & Rac GTPase & Epidermis & $\mathrm{CeAJ}$ & Ced; Mig; Emb & Larval screen & $\begin{array}{l}\text { Chen et al., 1993; } \\
\text { Ellis et al., 1991; } \\
\text { Reddien and } \\
\text { Horvitz, 2000; Soto } \\
\text { et al., 2002 }\end{array}$ \\
\hline pak-1 & $\begin{array}{l}\text { P21-activated } \\
\text { kinase }\end{array}$ & Epidermis & $\mathrm{CeAJ}$ & Unknown & Homol. & Chen et al., 1996 \\
\hline \multicolumn{7}{|c|}{$\begin{array}{l}\text { Abbreviations: ab., abnormal; ANK rep., ankyrin repeat; APC, Adenomatosis Polyposis Carcinoma; bind., binding; } \\
\text { Bioch., biochemical approach; CeAJ, C. elegans Apical Junction; Ced, Cell Death abnormal; CH, calponin } \\
\text { homology domain; def., defect; del, deletion screen; detach., detachment; Df, deficiency; E.c., excretory cell; EGF } \\
\text { rep., repeats found in the Epidermal Growth Factor; Emb, embryonic lethal; ep., epidermis; e.s., epitope screening; } \\
\text { FERM, domain found in Band 4.1, ezrin, radixin, moesin proteins; FN3 rep., fibronectin type III repeats; GAR, } \\
\text { growth arrest protein-2 related repeat; Homol., homology; IF, intermediate filament; Ig rep., immunoglobulin } \\
\text { superfamily repeat; int., intestine; LDL rep., Low Density Lipoprotein receptor A repeats; let, lethal; LRR, } \\
\text { Leucine-Rich repeat; mAb, monoclonal antibody; Mb, membrane; m.b., molecular biology; Mig, migration } \\
\text { defective; P., pharynx; PDZ, PSD-95/ Disc Large/ ZO-1 homology domain; PH, pleckstrin homology domain; P-I. } \\
\text { v., pharynx-intestinal valve; PLEC rep., plectin repeat; PM, plasma membrane; PTB, phosphotyrosine-binding } \\
\text { domain; R., rectum; rep., repeats; RNAi, RNA interference; SH3, src homology domain type 3; SPEC rep., spectrin } \\
\text { repeat; spermT., spermatheca; TM, transmembrane domain;; ut. Uterus; Vab, variably abnormal; V., vulva; VWA, } \\
\text { von Willebrand Factor A repeats. }\end{array}$} \\
\hline
\end{tabular}

\section{Epithelial cytoskeleton}

All three cytoskeletal networks can be found in C. elegans, in contrast to Drosophila which lacks intermediate filaments (IFs; Figure 1A). Except for IFs (see below), the expression and potential functions of individual cytoskeletal proteins in epithelia have not yet been fully characterized. 

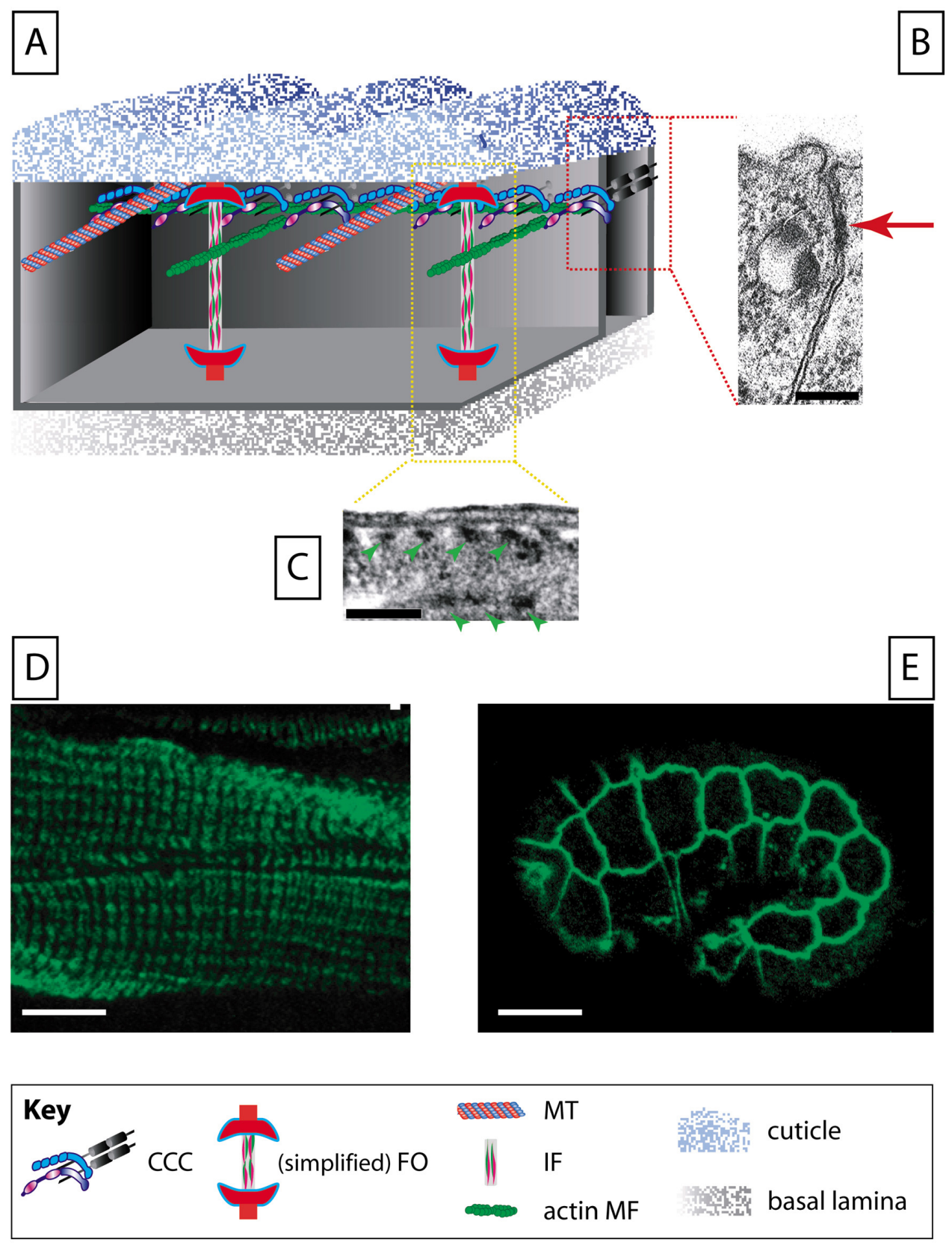

Figure 1. A schematic view of a non-seam epidermal cell. (A) All epidermal cells contain actin microfilaments and microtubules, but only dorsal and ventral epidermal cells contain intermediate filaments. In addition to cortical actin MFs, there are circumferential MF bundles, which are intermingled with MTs, and at least in embryos are less apical than MTs. It is unclear whether IFs are closer to MTs or to MFs. The cell-cell adhesion complex known as the CeAJ (C. elegans apical junction) has been simplified for clarity, leaving only the cadherin-catenin complex (CCC; for further details, see Fig. 3A). There are more CeAJs than actin MF bundles. Dorsal and ventral cells establish fibrous organelles (FOs), which are junctions with the extracellular matrix that mechanically couple muscles to the cuticle. For the sake of clarity, several FO components were not drawn. (B) Transmission electron micrograph of the adhesion complex between two ajacent epidermal cells in embryos (picture, courtesy of Dr. Renaud Legouis). Note that a single electron dense area can be observed (red arrow). (C) Transmission electron micrograph of FOs in the dorsal epidermis of embryos (green arrowheads, electron dense plaques). (D) Adult stained with the MH5 mAb showing the VAB-10A pattern in adults (a FO component). (E) Mid-staged embryo stained with the MH27 mAb showing the AJM-1 pattern (a CeAJ component) in the epidermis. Scale bars, $100 \mathrm{~nm}(\mathrm{~B}), 1 \mu \mathrm{m}(\mathrm{C}), 10 \mu \mathrm{m}$ (D, E). 

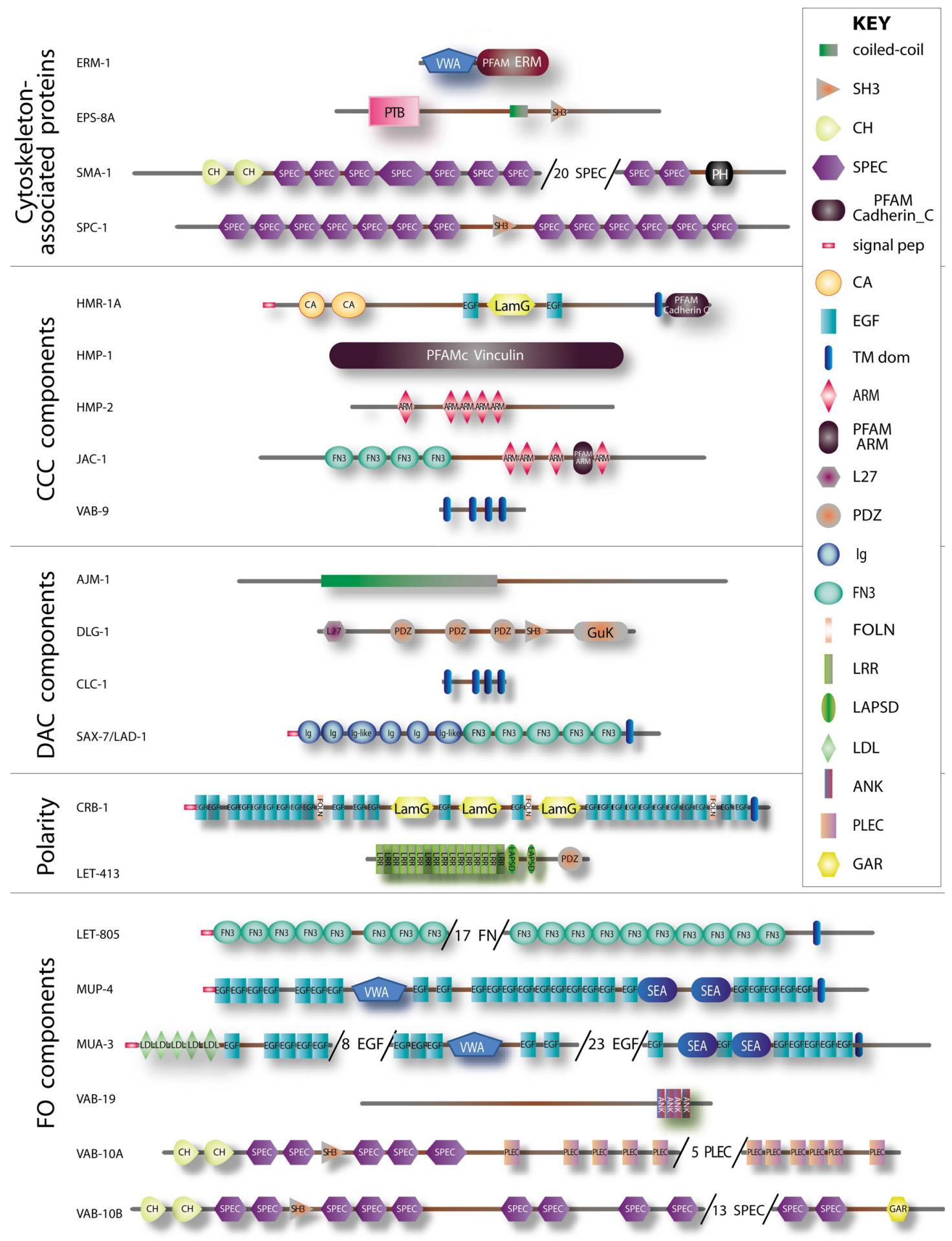

Figure 2. Structure of some epithelial junctional and cytoskeletal proteins. Schematic representation of the main epithelial-specific proteins that are further discussed in the text based on predictions made by the SMART software (smart.embl-heidelberg.org) for the longest existing isoform (for PAR-3 and PAR-6 see Asymmetric cell division and axis formation in the embryo). To fit proteins on a single page, some repeats were omitted in very large proteins (numbers in parentheses). Proteins are grouped as in Table I according to their membrane domain or presumptive function. The key for domains is shown on the left, except for those big enough to use larger fonts, and refer to SMART or PFAM domains (see Table I). Other symbols: ARM, armadillo repeat; CA, cadherin repeat; CCC, Cadherin/Catenin Complex; DAC, DLG-1/AJM-1 Complex; FO, Fibrous organelle; FOLN, Follistatin-N-terminal-like domain; LamG, laminin G domain; LAPSD, LRR and PDZ associated specific domain; L27, LIN-2 and LIN-7 domain; signal pep, signal peptide; TM dom, transmembrane domain. 


\subsection{Actin}

C. elegans has five closely related actins (ACT-1-5). In the epidermis, actin is found at the cell cortex, and, starting at the 1.5-fold stage, in circumferential bundles located under the furrows of the embryonic sheath, a structure thought to maintain the shape of the embryo during elongation (Costa et al., 1997; Priess and Hirsh, 1986). The specific molecular composition, organization and polarity of these bundles have not been established. In the intestine, actin microfilaments are enriched at the lumen (Gobel et al., 2004; Van Furden et al., 2004).

\subsection{Microtubules}

There are nine $\alpha$-tubulins (TBA-1-9) and six $\beta$-tubulins (TBB-1-6) in the $C$. elegans genome. Microtubules are oriented circumferentially in dorsal (hyp7) and ventral ( $\mathrm{P}$ cells) epidermal cells, where they might be intermingled with actin microfilament bundles, but are less well-organized in lateral seam cells (Costa et al., 1997; Priess and Hirsh, 1986). In the intestine, microtubules are enriched at the prospective lumen (Leung et al., 1999). How the microtubule cytoskeleton is anchored to the plasma membrane is not known.

\subsection{Intermediate filaments}

Among the eleven individual IFs (IFA-1-4, IFB-1-2, IFC-1-2, IFD-1-2, IFE-1), three (IFB-1, MUA-6/IFA-2 and IFA-3) are expressed in the epidermis, where they form short filaments between the apical and basal membranes located circumferentially at the interface between body wall muscles and the cuticle (Bartnik et al., 1986; Francis and Waterston, 1985; Francis and Waterston, 1991). In vitro polymerization suggests that IFB-1 forms obligate heteropolymers with IFA-2 and IFA-3, reminiscent of the vertebrate keratin system (Karabinos et al., 2003). Expression studies and genetic analysis further suggest that IFB-1/IFA-3 is the major heteropolymer in the embryonic epidermis, while IFB-1/MUA-6 is critical in the larval epidermis (Hapiak et al., 2003; Karabinos et al., 2003; Woo et al., 2004), with a possible minor contribution from IFC-1 (Karabinos et al., 2004). In the pharynx, IFA-1 forms heteropolymers with IFB-1 and is essential for feeding, while in the intestine three out of the four intestinal IFs must be removed to affect feeding and survival (Bossinger et al., 2004; Karabinos et al., 2001; Karabinos et al., 2003; Karabinos et al., 2004).

\section{Apical junction components}

Despite apparent differences, C. elegans epithelial cells look very similar to their vertebrate and fly counterparts. Although transmission electron microscopy identifies a single electron-dense junction in C. elegans (Figure 1B, 1E), whereas flies and vertebrates possess two junctional complexes, recent cellular and genetic analyses establish that worm epithelial cells do contain two molecularly and functionally distinct junctional complexes. These two complexes together are commonly referred to as the CeAJ (C. elegans Apical Junction; Figure 3A). 


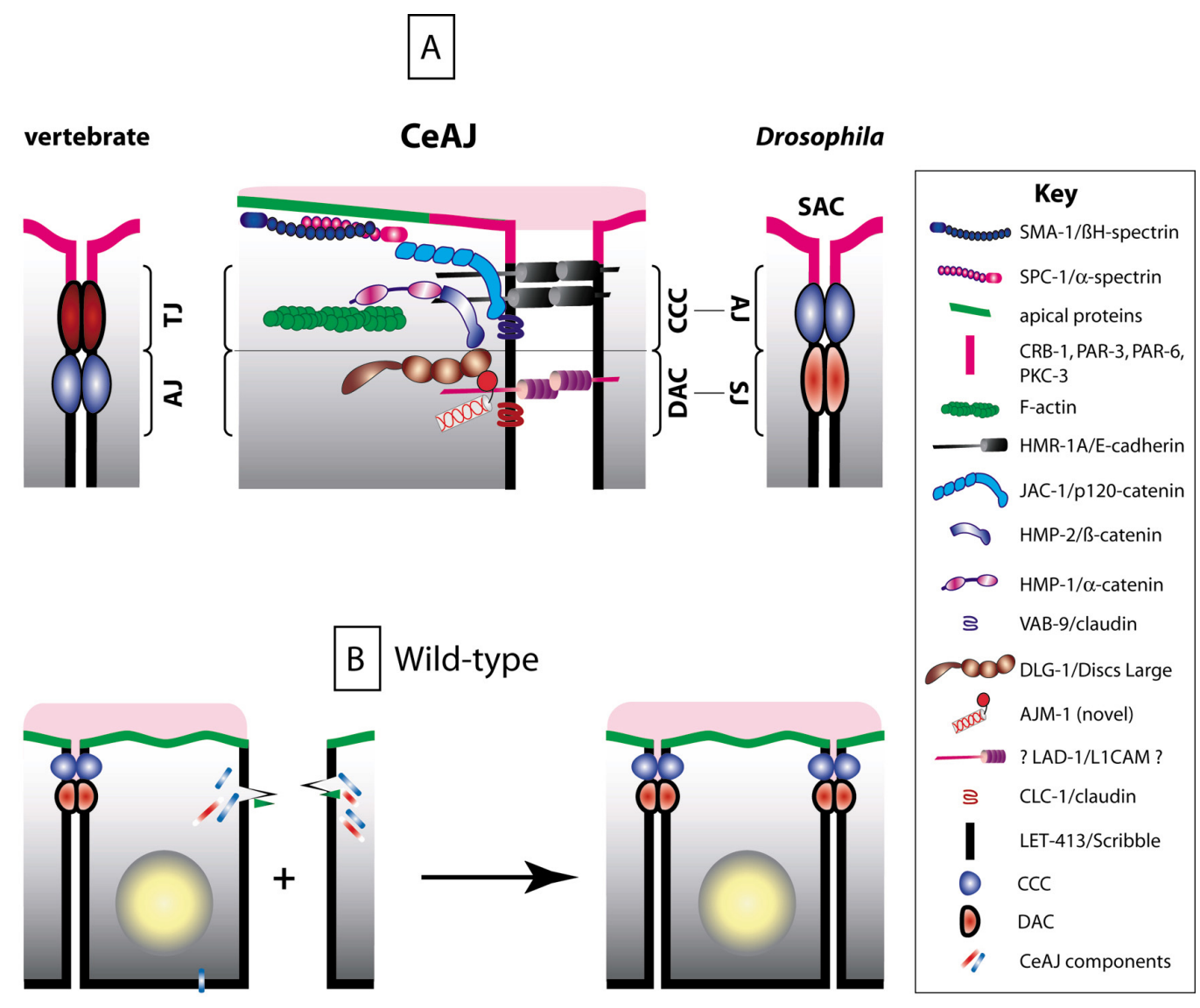

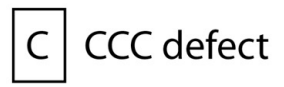



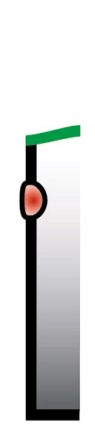
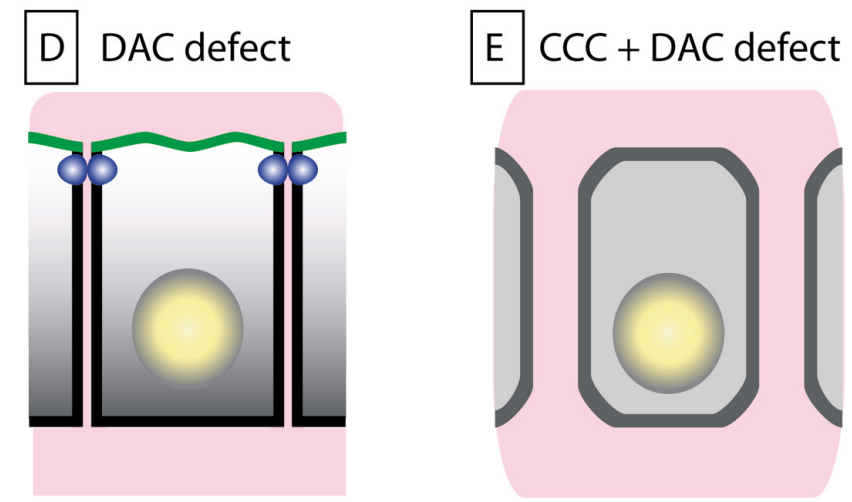

Figure 3. The CeAJ and cell-cell adhesion. (A) Schematic representation of known components CeAJ components. Like in vertebrates and Drosophila, C. elegans epithelial cells contain two adhesion complexes, the cadherin-catenin (CCC) and the DLG-1/AJM-1 (DAC) complexes. C. elegans is unique in three respects: (i) there is a single electron-dense area in the CeAJ (see Figure 1B); (ii) LET-413 does not colocalize with DLG-1 (as its homologue Scribble in Drosophila); (iii) PAR-3, PAR-6, PKC-3 and CRB-1 are present at the apical membrane in tubular organs (the existence of apical polarity determinants in epidermal cells is an open question). CeAJs from different epithelia contain the same set of proteins; notable differences concern the identity of the classical claudin-like protein (CLC-1 present in the pharynx, vulva and spermatheca; CLC-2 present in the lateral epidermis). The DAC complex might correspond to the electron-density in the CeAJ. Indeed, immunogold staining experiments localize AJM-1 at the electron density, and removal of DLG-1 or AJM-1 compromise the formation or the integrity, respectively, of the electron dense area of the CeAJ (Koppen et al., 2001; McMahon et al., 2001; Rostaing et al., 2004). Similar electron microscopy experiments with CCC components should clarify this point. (B) Once born, epidermal cells rapidly establish CeAJs (CCC, blue ball; DAC, red ellipse), which remain stable unless cells fuse. During ventral enclosure (+ sign), ventral epidermal cells extend actin-rich filopodial extensions towards the ventral midline (green triangles), where they must assemble a new CeAJ with their countralateral homologues through a cadherin/ HMR-1-dependent recruitment of other CCC, and presumably DAC, components (elongated rectangles; Raich et al., 1999). A similar actin-based process for junction formation has also been described in vertebrates (Vasioukhin et al., 2000). (C) Ventral cells in zygotic $h m r-1$, maternal and zygotic $h m p-2$ or maternal and zygotic $h m p-1$ mutants can extend towards the ventral midline but fail to establish junctions. However, adhesion remains normal elsewhere between cells that already had assembled a CeAJ. (D) Cell-cell adhesion is not impaired in mutants lacking the DAC. Paracellular gate function is defective in animals lacking the claudin-like protein CLC-1, a putative DAC component: pharyngeal cells fail to prevent a small fluorescent dye to leak between adjacent cells (pink material infiltrating between cells). (E) In animals lacking a CCC and a DAC protein (HMP-1 and DLG-1, or VAB-9 and DLG-1), cell adhesion is not maintained, causing epithelial cells to round up. 


\subsection{The cadherin-catenin complex (CCC)}

This complex is analogous in composition and to a large extent in function to the cadherin-catenin complex found in flies and vertebrates (Costa et al., 1998). The CCC includes homologues of the classical E-cadherin (HMR-1), $\alpha$-catenin (HMP-1), $\beta$-catenin (HMP-2), p120-catenin (JAC-1), and a distant claudin superfamily member (VAB-9; Costa et al., 1998; Pettitt et al., 2003; Simske et al., 2003; for further details, see The cadherin superfamily). The CCC is the most apical within the CeAJ (Koppen et al., 2001; McMahon et al., 2001).

\subsection{The DLG-1/AJM-1 complex (DAC)}

This complex is defined by two membrane-associated proteins, a Drosophila Discs-large homologue (DLG-1), and a new coiled-coil protein (AJM-1; Bossinger et al., 2001; Firestein and Rongo, 2001; Koppen et al., 2001; McMahon et al., 2001). DLG-1 and AJM-1 form a bona fide complex since they interact in vitro and are mutually dependent on each other for proper localization in vivo (Koppen et al., 2001; McMahon et al., 2001; Segbert et al., 2004).

The number of additional proteins belonging to the DAC and how DLG-1/AJM-1 is anchored to the membrane is not known. The claudin homologues CLC-1 or CLC-2, or the L1-CAM homologue LAD-1/SAX-7, which colocalize with AJM-1, might in some tissues fulfill this role (Asano et al., 2003; Chen et al., 2001).

\subsection{Additional proteins not assigned to a particular complex}

Several signaling proteins localize at the CeAJ or should do so based on homology, but their specific function is seldom known (Table 1; see Cox et al., 2004 for more references). Among them, the APC homologue APR-1 might be part of the CCC, since its Drosophila counterpart colocalizes with Armadillo/ $/$-catenin, and since apr-1 null mutants display an embryonic phenotype reminiscent of the $h m r-1$ ventral enclosure defect (Bienz and Hamada, 2004; Hoier et al., 2000).

\section{Cell adhesion, microfilament anchorage and gate function}

In vertebrates and Drosophila, adherens junctions maintain cell-cell adhesion and anchor actin microfilaments, while tight junctions (septate junctions in Drosophila) ensure a paracellular gate function. In addition, both junctional complexes contribute to maintenance of cell polarity and act as signaling platforms (Braga, 2002; Tsukita et al., 1999). In this framework, what is known about the cellular functions of the two CeAJ complexes?

\subsection{Cell-cell adhesion}

Mutations inactivating the CCC affect cell-cell adhesion, but only in certain circumstances. Mutations in $h m r-1 /$ E-cadherin, or simultaneous loss of zygotic and maternal $h m p-1 / \alpha$-catenin or $h m p-2 / \beta$-catenin prevent the stable assembly of new CeAJs during the morphogenetic movement known as ventral enclosure (for further details, see Epidermal Morphogenesis; Costa et al., 1998; Raich et al., 1999). Surprisingly however, such mutations do not impair cell adhesion among other epidermal cells or intestinal cells (Figure 3C).

The absence of the DLG-1/AJM-1 complex does not cause major cell adhesion defects, despite the absence of a detectable electron density in DLG-1 deficient embryos, or the presence of localized bubble-like separations between adjacent AJM-1 deficient cells (Figure 3D; Koppen et al., 2001; McMahon et al., 2001). Expression of a truncated form of the putative DAC component LAD-1/SAX-7 leads to morphogenetic defects that could be interpreted as adhesion defects (Chen et al., 2001). Identification of null alleles in this gene confirm that it is required in different ways for normal embryonic morphogenesis; in particular it is required for muscle attachment (see below), although the exact nature of the adhesion defect has not been established (Wang et al., 2005).

The unexpected observation that cell adhesion remains largely unaffected when one CeAJ complex is missing suggests that $C$. elegans, like vertebrates, might contain redundant adhesion systems (Sakisaka and Takai, 2004). The two CeAJ complexes likely cooperate to maintain cell adhesion, since simultaneous loss of a CCC and DAC components causes severe adhesion defects in the epidermis and the intestine (Figure 3E; Segbert et al., 2004; Simske et al., 2003; L. McMahon and M. Labouesse, unpublished results). 


\subsection{Paracellular gate function}

The strong sequence similarity between DLG-1 and Discs Large, which in Drosophila associates with septate junctions, and the occurrence of vacuoles in ajm-1 and $d l g-1$ null mutants, raised the possibility that the DAC could perform a role analogous to septate junctions in maintaining paracellular gating (Koppen et al., 2001). Indirect support for this view has come from the observation that a low-molecular weight fluorescent dye can diffuse between phrayngeal cells in animals lacking CLC-1, a possible DAC component (Figure 3D; Asano et al., 2003).

\subsection{Actin anchoring}

In the epidermis, the CCC complex is essential to anchor the circumferential actin bundles, since lack of HMP-1/ $\alpha$-catenin or HMP-2/ $\beta$-catenin causes them to detach from the CeAJ (Figure 4B; Costa et al., 1998). Consistent with the observation that drugs inhibiting actin polymerization prevent embryonic elongation (Priess and Hirsh, 1986), hmp-1 and hmp-2 mutations block elongation, while loss of JAC-1/p120 catenin enhances the elongation defect of a weak hmp-1 mutation (Costa et al., 1998; Pettitt et al., 2003). The presence of redundant adhesion systems in $C$. elegans has made it possible to separate the actin anchoring and the cell-cell adhesion functions of the CCC.

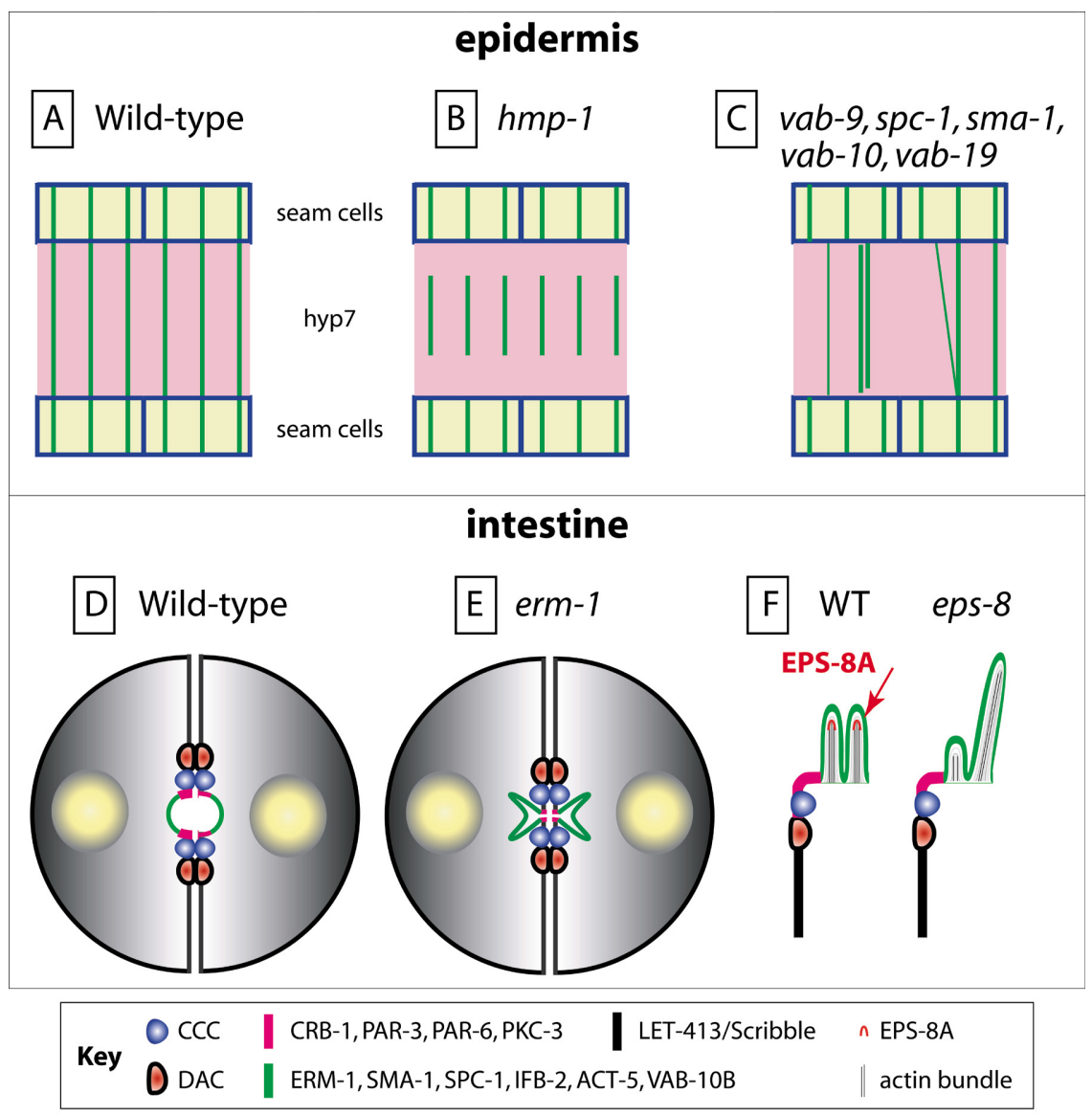

Figure 4. Anchoring of actin microfilaments. (A) Flat-mount representation of the dorsal half of an embryo (for a more complete view, see Figure 6), with seam cells (light yellow) and the main dorsal epidermal syncytium hyp7 (pink; anterior to the left, posterior to the right). Circumferential actin bundles (horizontal green lines) are anchored to the CCC (blue lines). (B) In hmp-l or hmp-2 mutants, actin bundles are not attached dorsally (their attachment is not compromised ventrally and laterally); due to morphogenetic forces, they snap back to the middle of hyp7. (C) In mutants for the CCC component VAB-9, the apical spectrin SPC-1/SMA-1, the FO components VAB-19 and VAB-10, MFs randomly form thicker bundles, are not properly aligned or can locally detach from the CeAJ. (D) Schematic representation of two intestinal cells. (E) ERM-1 is required to anchor the actin cytoskeleton at the gut lumen. In animals strongly defective for erm-1, or partially defective for erm-1 and sma-1, or erm-1 and act-5, the lumen folds inside the cells, causing gut constrictions. However junctions and epithelial polarity are not affected. (F) Enlarged view of the intestinal lumen and brush border in wild-type animals (left), showing the localization of EPS-8A which binds actin barbed ends through a novel domain found at its C-terminus. In larvae homozygous for a strong eps- 8 allele or after RNAi against the eps- $8 \mathrm{~A}$ isoform (right), microvilli have irregular sizes and orientations or can be missing (note that RNAi against all isoforms is embryonic lethal, indicating that eps- 8 might have a maternal component). 
Several proteins acting either within the CCC, at the apical membrane, or within fibrous organelles (see below) ensure the regular distribution of microfilament bundles in the epidermis (Figure 4C). For instance, in mutants affecting the CCC component VAB-9/claudin or the $\alpha$-spectrin/SPC-1, microfilaments often form thicker bundles and thereby reduce elongation (Ding et al., 2003; Norman and Moerman, 2002; Simske et al., 2003).

In the intestine, the Ezrin-Radixin-Moesin homologue ERM-1, together with SMA- $1 / \beta_{\mathrm{H}}$-spectrin, act as scaffolding proteins to anchor actin filaments at the lumen and ensure proper lumen formation (Göbel et al., 2004; Van Furden et al., 2004). In particular, strong RNAi against erm-l causes a severe reduction of apical microfilaments and gut lumen constrictions (Figure 4E). Although ERM-1 is expressed in other epithelia, it only appears essential for the development of epithelia not lined by a cuticle (Göbel et al., 2004; Van Furden et al., 2004). Another protein critical for lumen formation and gut function is EPS-8A, the long isoform of the C. elegans homologue of the receptor tyrosine kinase (RTK) receptor substrate Eps8, a protein that in vertebrates links RTK and Rac GTPase signaling. EPS-8A is localized at the tips of the brush border intestinal microvilli, where it acts as a barbed-end actin-capping factor that stabilizes microvilli (Croce et al., 2004). When EPS-8A is removed by RNAi or a mutation, the gut lumen becomes strongly enlarged, causing larval lethality.

\section{Assembly of apical junctions and establishment of epithelial polarity}

In Drosophila, the interplay between three scaffolding complexes: basolaterally the Scribble/Discs Large/Lethal giant larvae complex, and apically the Bazooka/DmPAR-6/DaPKC and Crumbs/Stardust/Disc Lost complexes, specify epithelial polarity (Knust and Bossinger, 2002; Muller and Bossinger, 2003; Nelson, 2003). In C. elegans, the establishment of epithelial polarity may involve different mechanisms, since PAR-3, PAR-6 and PKC-3 have so far not been found in the epidermis (Bossinger et al., 2004; McMahon et al., 2001), while some other homologues of key Drosophila polarity proteins are not expressed in equivalent membrane domains. Current observations point to the existence of multiple, probably redundant, cues to position junctions.

\subsection{Cellular processes involved in specifying polarity}

The establishment of epithelial polarity often requires slightly different processes in cells that form sheets or tubes (Nelson, 2003; Zegers et al., 2003). During development of the epidermis, CeAJ components are assembled in a step-wise fashion. They are initially found along the lateral membrane, and then rapidly adopt their final apical distribution (Figure 5A). It is not clear, however, whether CeAJ components are degraded laterally, actively transported apically or prevented from docking basolaterally (McMahon et al., 2001).

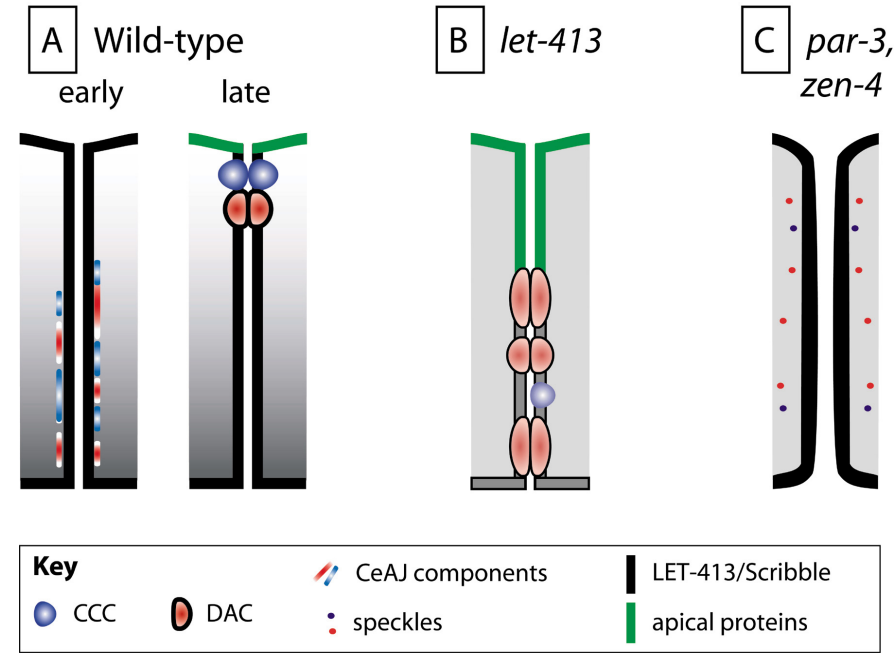

Figure 5. Establishment of epithelial cell polarity. (A) In epithelial cells forming a sheet (the epidermis), individual components of the future CeAJ are initially found along the lateral membrane (early). Subsequently, they coalesce into the CeAJ apically (late). LET-413 is present in epithelial precursors and becomes restricted to the basolateral membrane in epithelial cells while they differentiate. (B) In let-413 mutants, ectopic electron dense junctions are found along the lateral membrane, suggesting that LET-413 might promote apical coalescence of CeAJ components (see A). Apical markers of the epidermis (CHE-14) and the intestine (PAR-3, PAR-6, IFB-2, ERM-1) also become gradually mislocalized along the lateral membrane, which might be due to the junctional defect or reflect an additional role of LET-413. (C) Some epithelial cells that form a tube require the activity of PAR-3 (e.g., in the distal spermatheca), or the ZEN-4/CYK-4 complex (in arcade cells). In animals lacking these proteins, cell polarity is not established, CeAJ components form discrete speckles, and the cytoskeleton is not enriched at the prospective apical lumenal side (not illustrated). 
In the intestine, the pharynx and the excretory cell, epithelial polarity appears to start by the formation of small vesicles, whose expansion contributes to form the lumen (Buechner et al., 1999; Leung et al., 1999). Microtubules and actin microfilaments are enriched at the prospective lumen, where they play a critical role in gut tubulogenesis (Leung et al., 1999). As in the epidermis, the CeAJ assembles in a step-wise manner, except that CeAJ components intially accumulate in puncta at the midline (future apical surface) to subsequently adopt a sub-apical continuous distribution (Bossinger et al., 2001; Leung et al., 1999).

\subsection{Defining the basal position of the CeAJ}

In the epidermis, the basolateral protein LET-413, the only C. elegans Scribble homologue, positions the CeAJ presumably by promoting its apical condensation (Legouis et al., 2000; McMahon et al., 2001). In LET-413 deficient embryos, and depending on authors, DLG-1, AJM-1 and HMP-1/ $\alpha$-catenin, remain lateral leading to lateral assembly of electron dense junctions (Figure 5B; Legouis et al., 2000; McMahon et al., 2001), or reach their sub-apical position less efficiently (Koppen et al., 2001). Moreover, in the epidermis as well as in the intestine, apical membrane markers progressively spread into the lateral membrane, suggesting that LET-413 acts to maintain polarity (Bossinger et al., 2004; Koppen et al., 2001; McMahon et al., 2001; Segbert et al., 2004). Although LET-413 biochemical activity is unknown, it has been predicted that it might act through a small GTPase. Its N-terminal leucine-rich repeats, which mediate basolateral localization, show good similarity with the Ras-interacting protein SUR-8 (Legouis et al., 2003).

\subsection{Apical proteins involved in specifying polarity and tubulogenesis}

PAR-3, PAR-6 and PKC-3 are present at the apical membrane of tubular organs, where their role has been difficult to assess owing to their early requirement in development (Pellettieri and Seydoux, 2002). Roles for PAR-3 and PAR-6 in epithelial polarity have been uncovered in two specific cases. Indirect evidence in favor of a role for C. elegans PAR proteins in establishing cell polarity initially came from very elegant experiments in which PAR-3 and PAR-6 were only provided to the zygote (Nance et al., 2003). Although blastomeres after the 8-cell stage are not truly epithelial, they are polarized and require the activity of PAR-3/ PAR- 6 to maintain cell-cell adhesion and restrict PAR-1 and PAR-2 to their basolateral surfaces. Lack of PAR-3 or PAR-6 considerably slows down ingression of gut precursors during gastrulation (Nance et al., 2003). RNAi feeding in larvae also established that PAR-3 is required in the distal spermatheca to specify polarity and to assemble the CeAJ (Figure 5C). In turn, absence of the CeAJ compromises signaling between the spermatheca and the germline (Aono et al., 2004).

Several observations indicate that establishing cell polarity in the intestine involves multiple parallel cues. For instance, the Crumbs homologue CRB-1, an apical protein in the gut, plays an ancillary role in cell polarity which can be revealed by the simultaneous knock-down of LET-413, HMP-1/ $\alpha$-catenin and CRB-1 (Bossinger et al., 2004; Bossinger et al., 2001). Similarly, the Moesin homologue ERM-1 is not essential for junction assembly or cell polarity, unless it is inactivated together with $h m r-1 / \mathrm{E}$-cadherin, in which case the CeAJ is missing in many places (as observed after the simultaneous loss of a DAC and CCC components; see Figure 3E; Speck et al., 2003; Van Furden et al., 2004).

Two new players, zen-4 and $c y k-4$, have recently been identified as factors required for epithelialization of arcade cells during pharynx tubulogenesis (Figure 5C). Normally, arcade cells undergo a mesenchymal-epithelial transition to assemble typical CeAJs, express PAR-3/PKC-3 at their apical membrane and create a tube (Portereiko and Mango, 2001; Portereiko et al., 2004). In zen-4 or cyk-4 mutants, these steps fail, perhaps because the arcade microtubule and actin cytoskeletons are disorganized (Portereiko et al., 2004). The conventional kinesin ZEN-4/MKLP1 and the Rho GTPase-activating protein CYK-4 were previously described to form a complex that bundles microtubules and constructs the spindle midzone during cytokinesis (Glotzer, 2001). Whether and how the functions of the ZEN-4/CYK-4 complex in cytokinesis and epithelialization are related is not yet known.

\section{Junction disassembly and cell fusion}

Multiple cell fusion events occur during C. elegans development, which directly affect its morphogenesis and organogenesis. Confocal and transmission electron microscopy have suggested that fusion is initiated by a pore-forming mechanism originating at a single point located within or in very close proximity of a CeAJ (Mohler et al., 1998). This pore is then thought to expand by vesiculation of the membrane (Mohler et al., 1998). 
While several mutants have been described that affect the decision to fuse, the only gene known to be necessary and sufficient for the fusion process itself is eff-1 (Mohler et al., 2002). In eff-1 mutants, cell fusion is blocked at an early step, presumably at the initiation and expansion steps (Mohler et al., 2002). Ectopic expression of EFF-1 triggers fusion between cells that normally do not fuse, resulting in cytoplasmic mixing and the disappearance of CeAJs within one hour of expression (Shemer et al., 2004).

\section{Fibrous organelles: junctions with the extracellular matrix and mechanical coupling}

C. elegans dorsal and ventral epidermal cells possess a major adhesion complex, called the fibrous organelle (FO), which mediates attachment to muscles and the cuticle, or which transmits cuticle deformation to mechanosensory touch neurons (Francis and Waterston, 1991). Similar structures are also found in the pharyngeal marginal cells. FOs look ultrastructurally, functionally and to some extent molecularly like type I hemidesmosomes (HDs). In vertebrates, HDs attach the basal layer of the epidermis to the basal lamina and are essential to anchor keratin filaments (Nievers et al., 1999).

\subsection{Fibrous organelles resemble type I hemidesmosomes}

Transmission electron microscopy reveals the presence of regularly spaced electron densities at the apical and basal plasma membranes of the ventral and dorsal epidermis, in regions overlying body wall, vulval, uterine and anal muscles (Figure 1C-D, Figure 6A; Francis and Waterston, 1985; Francis and Waterston, 1991). These plaques, together with the dense array of filaments connecting them, correspond to FOs.

A key FO component is an isoform of the gene $v a b-10$, VAB-10A, resembling plectin and BPAG1e which in HDs connect keratin filaments to integrin and BPAG2 adhesion receptors (Bosher et al., 2003; Nievers et al., 1999). Immunogold staining localizes $\mathrm{VAB}-10 \mathrm{~A}$ to a region enriched in filaments, while genetic experiments show that VAB-10A is required to anchor IFs (Figure 6A-B; Bosher et al., 2003). Genetic and immunofluorescence experiments argue that the filaments associated with FOs correspond to the IFB-1/IFA-3 and IFB-1/IFA-2 heterodimers (see cytoskeleton section; Figure 6A; Hapiak et al., 2003; Karabinos et al., 2003; Woo et al., 2004). Besides VAB-10A and IFs, another presumptive FO component is VAB-19, which is homologous to the tumor suppressor Kank (Figure 6A; Ding et al., 2003).

The transmembrane adhesion molecules predicted to link VAB-10A and IFs are MUA-3 and MUP-4 on the apical side of the epidermis, and myotactin/LET-805 on its basal side (Figure 6A; Bercher et al., 2001; Hong et al., 2001; Hresko et al., 1999). These proteins are unrelated to integrins and BPAG2, implying that HDs and FOs are not strictly equivalent (Table 1). Intriguingly, however, the extracellular domains of MUA-3 and MUP-4 show weak similarity to matrilins, which are components of vertebrate tendons, a structure enriched in collagens like the cuticle (Hahn and Labouesse, 2001).

Akin to the skin blistering phenotype observed in patients compromised for an HD component, mutations inactivating FO components cause the epidermis to detach from the cuticle on its apical side and from muscles on its basal side (Figure 6B-C; Bercher et al., 2001; Bosher et al., 2003; Ding et al., 2003; Hapiak et al., 2003; Hong et al., 2001; Hresko et al., 1999; Karabinos et al., 2003; Woo et al., 2004). Muscle contractions are responsible for this phenotype since inhibiting their activity strongly reduces detachment (Bosher et al., 2003; Ding et al., 2003). The ensuing detachment causes elongation defects and embryonic lethality, except in mua-3 and mua-6/ifa-2 mutants, which only affect larvae, suggesting that mиа-3 and mиа- 6 fulfill a specialized role associated with the presence of a cuticle. 


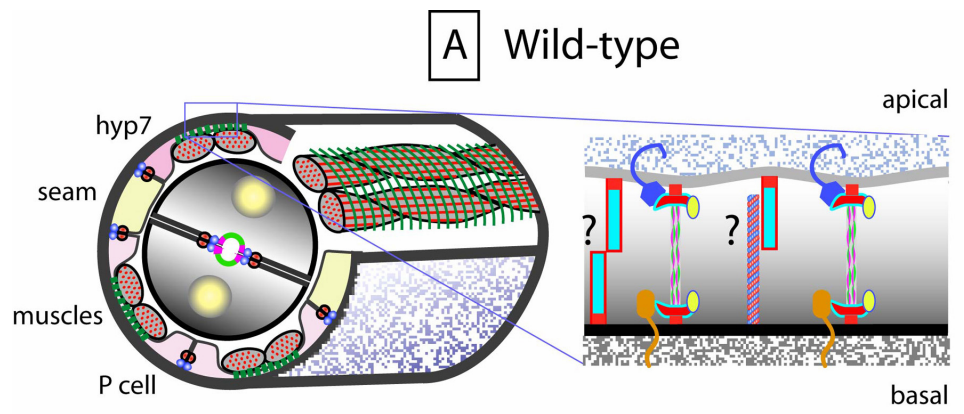

B $v a b-10 A$
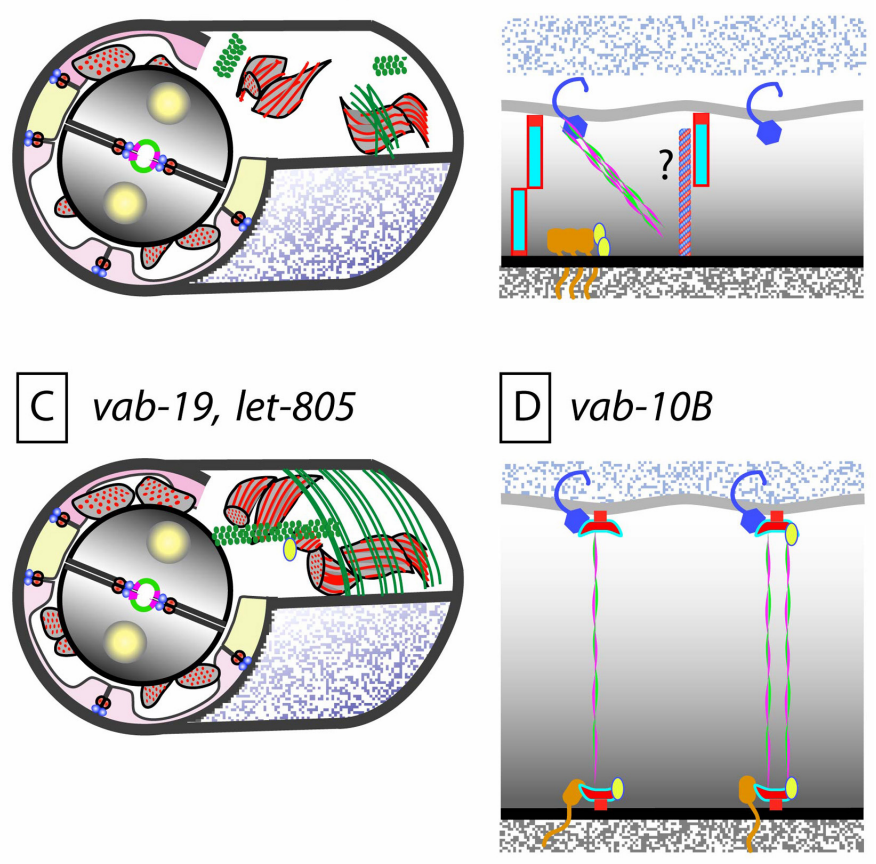

\begin{tabular}{|c|c|c|c|c|c|}
\hline Key &  & \multicolumn{4}{|c|}{$\begin{array}{l}\text { muscle + FOs } \\
\text { (transverse view) }\end{array}$} \\
\hline & mature FO & 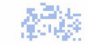 & cuticle & Xity & basal lamina \\
\hline  & immature FO & & MUP-4, & & myotactin \\
\hline & detached mus & & VAB-10 & & VAB-10B \\
\hline 0 & VAB-19 & $\|$ & IFs & & MT \\
\hline
\end{tabular}

Figure 6. Structure and function of fibrous organelles. (A - left) Schematized section of an animal in which the cuticle overlaying the dorsal epidermis was removed; muscles are oriented longitudinally, fibrous organelles (FOs) circumferentially. FOs are found where muscles make contacts with the dorsal and ventral epidermis; due to FO attachments, the epidermis flattens out in regions overlying muscles (50 to $100 \mathrm{~nm}$ in larvae; A - right) FOs correspond to a complex formed basally by the myotactin/LET-805 receptor or apically by the homologous (see Figure 2) MUA-3 and MUP-4 receptors, the plectin/BPAG1e-like VAB-10A, the ankyrin-repeat protein VAB-19/Kank, and the intermediate filament heterodimers IFB-1/IFA-2 or IFB-1/IFA-3. How these proteins interact with each other is not known, besides that MUP-4, MUA-3 and VAB-10 have potential IF-binding domains. VAB-10B, another MACF-like $v a b-10$ isoform present in muscle-epidermis contact areas, is found in comma embryos at the apical and basal plasma membrane. At later stages, it is unknown whether VAB-10B remains basal and apical or only apical (as in the intestine; see question marks). (B - left) In $v a b-10 A$ mutants, muscles are not attached to the epidermis and collapse inside the embryo; FOs are strongly disorganized/absent. (B - right) At the cellular level, the epidermis detaches from the embryonic sheath (or the cuticle at later stages); IFs, myotactin and VAB-19 have a very abnormal distribution or form aggregates. (C) A similar phenotype, albeit slightly less severe, is observed in let-805/myotactin or vab-19/Kank mutants; muscles detach, and at the cellular level, FOs fail to evolve from foci to circumferential lines (left), or they stretch from one seam to the other (right). (D) In $v a b-10 B$ mutants, the distance between the apical and basal plasma membranes increases. At least two possibilities could explain this phenotype (see question marks in A-right): either in wild-type embryos two apical and basal VAB-10B proteins form homodimers to oppose thickening, or, as it is often the case in vertebrate epithelial cells, there are apico-basally oriented microtubules that could be anchored by VAB-10B. FO integrity is also partially defective in $v a b-10 B$ mutants, indicating that VAB-10A and VAB-10B could be mutually interdependent to maintain their organization. 


\subsection{Assembly of fibrous organelles}

FO components initially appear as foci at the apical and basal epidermal membranes, which progressively evolve into short circumferential bands overlying muscles after the pretzel stage (Figure 6A; Francis and Waterston, 1991). FO assembly requires input from muscles (Hresko et al., 1999). It is still unclear, however, whether muscles simply stabilize FOs, or whether they induce the expression of FO components, much as Drosophila muscles induce the differentiation of tendon cells (Volk, 1999).

The initial assembly of FO components at the muscle-epidermis interface does not depend on other FO components, but their fine patterning does (Figure 6B-C). In the absence of VAB-10A, other components get dispersed or they aggregate into abnormal bundles (Bosher et al., 2003). Likewise, when myotactin/LET-805 is absent, FOs are not restricted to a narrow area where muscles should be and VAB-19 becomes dispersed in a broad area (Ding et al., 2003; Hresko et al., 1999). Reciprocally, when VAB-19 is absent, the distribution of IFs is enlarged and the myotactin pattern fails to evolve into a pattern of circumferential bands (Ding et al., 2003).

Maintenance of FOs depends also on VAB-10B, another VAB-10 isoform, whose distribution is intermingled with that of VAB-10A (Figure 6A, D; Bosher et al., 2003). The reason for the progressive loss of FOs in vab-10B mutants is unclear, and may be due to a thickening of the epidermis, and/or a failure to maintain the integrity of the actin and microtubule cytoskeleton after the two-fold stage (Landmann and Labouesse, unpublished).

\section{Conclusions and future directions}

Seven years ago, we knew essentially nothing about epithelial junctions in C. elegans. The identification of several key actors involved in building junctions thus represents a major step forward. Yet much remains to be learned, particularly in analyzing the molecular relationship between the three cytoskeletal networks and in defining how adhesion complex can modulate signaling. C. elegans has small cells and does not easily lend itself to biochemical analysis. Nonetheless, some recent technical developments, such as rapid cameras with better resolution, reagents that can monitor protein activity or protein-protein interaction in vivo, the TAP-tag method of purifying protein complexes, should allow researchers in the field to make up for those disadvantages. When combined with the traditional power of worm genetics, these techniques offer promise towards elucidating how adhesion complexes can regulate morphogenesis, or how compromising junction integrity can result in human diseases.

\section{Acknowledgements}

I thank past and present members of the Labouesse lab for lively and useful discussions, in particular Renaud Legouis for critical reading of the manuscript. Work in my laboratory is funded by institutional funds from the CNRS, INSERM and Hôpitaux Universitaires de Strasbourg, and by grants from the European Community, the Association pour la Recherche sur le Cancer and the Association Française contre les Myopathies.

\section{References}

Aono, S., Legouis, R., Hoose, W.A., and Kemphues, K.J. (2004). PAR-3 is required for epithelial cell polarity in the distal spermatheca of C. elegans. Development 131, 2865-2874. Abstract Article

Asano, A., Asano, K., Sasaki, H., Furuse, M., and Tsukita, S. (2003). Claudins in Caenorhabditis elegans: their distribution and barrier function in the epithelium. Curr. Biol. 13, 1042-1046. Abstract Article

Bartnik, E., Osborn, M., and Weber, K. (1986). Intermediate filaments in muscle and epithelial cells of nematodes. J. Cell Biol. 102, 2033-2041. Abstract Article

Bercher, M., Wahl, J., Vogel, B.E., Lu, C., Hedgecock, E.M., Hall, D.H., and Plenefisch, J.D. (2001). mua-3, a gene required for mechanical tissue integrity in Caenorhabditis elegans, encodes a novel transmembrane protein of epithelial attachment complexes. J. Cell Biol. 154, 415-426. Abstract Article

Bienz, M., and Hamada, F. (2004). Adenomatous polyposis coli proteins and cell adhesion. Curr. Opin. Cell Biol. 16, 528-535. Abstract Article 
Bosher, J.M., Hahn, B.S., Legouis, R., Sookhareea, S., Weimer, R.M., Gansmuller, A., Chisholm, A.D., Rose, A.M., Bessereau, J.L., and Labouesse, M. (2003). The Caenorhabditis elegans vab-10 spectraplakin isoforms protect the epidermis against internal and external forces. J. Cell Biol. 161, 757-768. Abstract Article

Bossinger, O., Fukushige, T., Claeys, M., Borgonie, G., and McGhee, J.D. (2004). The apical disposition of the Caenorhabditis elegans intestinal terminal web is maintained by LET-413. Dev. Biol. 268, 448-456. Abstract Article

Bossinger, O., Klebes, A., Segbert, C., Theres, C., and Knust, E. (2001). Zonula adherens formation in Caenorhabditis elegans requires dlg-1, the homologue of the Drosophila gene discs large. Dev. Biol. 230, $29-42$. Abstract Article

Braga, V.M. (2002). Cell-cell adhesion and signalling. Curr. Opin. Cell Biol. 14, 546-556. Abstract Article

Buechner, M., Hall, D.H., Bhatt, H., and Hedgecock, E.M. (1999). Cystic canal mutants in Caenorhabditis elegans are defective in the apical membrane domain of the renal (excretory) cell. Dev. Biol. 214, 227-241. Abstract Article

Chen, L., Ong, B., and Bennett, V. (2001). LAD-1, the Caenorhabditis elegans L1CAM homologue, participates in embryonic and gonadal morphogenesis and is a substrate for fibroblast growth factor receptor pathway-dependent phosphotyrosine-based signaling. J. Cell Biol. 154, 841-855. Abstract Article

Chen, W., Chen, S., Yap, S.F., and Lim, L. (1996). The Caenorhabditis elegans p21-activated kinase (CePAK) colocalizes with CeRac1 and CDC42Ce at hypodermal cell boundaries during embryo elongation. J. Biol. Chem. 271, 26362-26368. Abstract Article

Chen, W., Lim, H.H., and Lim, L. (1993). The CDC42 homologue from Caenorhabditis elegans. Complementation of yeast mutation. J. Biol. Chem. 268, 13280-13285. Abstract

Chen, W., Lim, H.H., and Lim, L. (1993). A new member of the ras superfamily, the rac1 homologue from Caenorhabditis elegans. Cloning and sequence analysis of cDNA, pattern of developmental expression, and biochemical characterization of the protein. J. Biol. Chem. 268, 320-324. Abstract

Costa, M., Draper, B.W., and Priess, J.R. (1997). The role of actin filaments in patterning the Caenorhabditis elegans cuticle. Dev. Biol. 184, 373-384. Abstract Article

Costa, M., Raich, W., Agbunag, C., Leung, B., Hardin, J., and Priess, J.R. (1998). A putative catenin-cadherin system mediates morphogenesis of the Caenorhabditis elegans embryo. J. Cell Biol. 141, 297-308. Abstract Article

Cox, E.A., Tuskey, C., and Hardin, J. (2004). Cell adhesion receptors in C. elegans. J. Cell Sci. 117, $1867-1870$. Abstract Article

Croce, A., Cassata, G., Disanza, A., Gagliani, M.C., Tacchetti, C., Malabarba, M.G., Carlier, M.F., Scita, G., Baumeister, R., and Di Fiore, P.P. (2004). A novel actin barbed-end-capping activity in EPS-8 regulates apical morphogenesis in intestinal cells of Caenorhabditis elegans. Nat. Cell Biol. 6, 1173-1179. Abstract Article

Ding, M., Goncharov, A., Jin, Y., and Chisholm, A.D. (2003). C. elegans ankyrin repeat protein VAB-19 is a component of epidermal attachment structures and is essential for epidermal morphogenesis. Development 130, 5791-5801. Abstract Article

Ding, M., Woo, W.M., and Chisholm, A.D. (2004). The cytoskeleton and epidermal morphogenesis in C. elegans. Exp. Cell Res. 301, 84-90. Abstract Article

Dodemont, H., Riemer, D., Ledger, N., and Weber, K. (1994). Eight genes and alternative RNA processing pathways generate an unexpectedly large diversity of cytoplasmic intermediate filament proteins in the nematode Caenorhabditis elegans. Embo J. 13, 2625-2638. Abstract

Ellis, R.E., Jacobson, D.M., and Horvitz, H.R. (1991). Genes required for the engulfment of cell corpses during programmed cell death in Caenorhabditis elegans. Genetics 129, 79-94. Abstract 
Firestein, B.L., and Rongo, C. (2001). DLG-1 is a MAGUK similar to SAP97 and is required for adherens junction formation. Mol. Biol. Cell 12, 3465-3475. Abstract

Francis, G.R., and Waterston, R.H. (1985). Muscle organization in Caenorhabditis elegans: localization of proteins implicated in thin filament attachment and I-band organization. J. Cell Biol. 101, 1532-1549. Abstract Article

Francis, R., and Waterston, R.H. (1991). Muscle cell attachment in Caenorhabditis elegans. J. Cell Biol. 114, 465-479. Abstract Article

Gatewood, B.K., and Bucher, E.A. (1997). The mup-4 locus in Caenorhabditis elegans is essential for hypodermal integrity, organismal morphogenesis and embryonic body wall muscle position. Genetics 146, 165-183. Abstract

Glotzer, M. (2001). Animal cell cytokinesis. Annu. Rev. Cell Dev. Biol. 17, 351-386. Abstract Article

Gobel, V., Barrett, P.L., Hall, D.H., and Fleming, J.T. (2004). Lumen morphogenesis in C. elegans requires the membrane-cytoskeleton linker erm-1. Dev. Cell 6, 865-873. Abstract Article

Hahn, B.S., and Labouesse, M. (2001). Tissue integrity: hemidesmosomes and resistance to stress. Curr. Biol. 11, R858-R861. Abstract Article

Hammarlund, M., Davis, W.S., and Jorgensen, E.M. (2000). Mutations in $\beta$-spectrin disrupt axon outgrowth and sarcomere structure. J. Cell Biol. 149, 931-942. Abstract Article

Hapiak, V., Hresko, M.C., Schriefer, L.A., Saiyasisongkhram, K., Bercher, M., and Plenefisch, J. (2003). mua-6, a gene required for tissue integrity in Caenorhabditis elegans, encodes a cytoplasmic intermediate filament. Dev. Biol. 263, 330-342. Abstract Article

Harrington, R.J., Gutch, M.J., Hengartner, M.O., Tonks, N.K., and Chisholm, A.D. (2002). The C. elegans LAR-like receptor tyrosine phosphatase PTP-3 and the VAB-1 Eph receptor tyrosine kinase have partly redundant functions in morphogenesis. Development 129, 2141-2153. Abstract

Hoier, E.F., Mohler, W.A., Kim, S.K., and Hajnal, A. (2000). The Caenorhabditis elegans APC-related gene apr-1 is required for epithelial cell migration and Hox gene expression. Genes Dev. 14, 874-886. Abstract

Hong, L., Elbl, T., Ward, J., Franzini-Armstrong, C., Rybicka, K.K., Gatewood, B.K., Baillie, D.L., and Bucher, E.A. (2001). MUP-4 is a novel transmembrane protein with functions in epithelial cell adhesion in Caenorhabditis elegans. J. Cell Biol. 154, 403-414. Abstract Article

Hresko, M.C., Schriefer, L.A., Shrimankar, P., and Waterston, R.H. (1999). Myotactin, a novel hypodermal protein involved in muscle-cell adhesion in Caenorhabditis elegans. J. Cell Biol. 146, 659-672. Abstract Article

Hutter, H., Vogel, B.E., Plenefisch, J.D., Norris, C.R., Proenca, R.B., Spieth, J., Guo, C., Mastwal, S., Zhu, X., Scheel, J., and Hedgecock, E.M. (2000). Conservation and novelty in the evolution of cell adhesion and extracellular matrix genes. Science 287, 989-994. Abstract Article

Jantsch-Plunger, V., G_nczy, P., Romano, A., Schnabel, H., Hamill, D., Schnabel, R., Hyman, A.A., and Glotzer, M. (2000). CYK-4: A Rho family gtpase activating protein (GAP) required for central spindle formation and cytokinesis. J. Cell Biol. 149, 1391-1404. Abstract Article

Karabinos, A., Schmidt, H., Harborth, J., Schnabel, R., and Weber, K. (2001). Essential roles for four cytoplasmic intermediate filament proteins in Caenorhabditis elegans development. Proc. Natl. Acad. Sci. USA 98, $7863-7868$. Abstract Article

Karabinos, A., Schulze, E., Klisch, T., Wang, J., and Weber, K. (2002). Expression profiles of the essential intermediate filament (IF) protein A2 and the IF protein C2 in the nematode Caenorhabditis elegans. Mech. Dev. 117, 311-314. Abstract Article 
Karabinos, A., Schulze, E., Schunemann, J., Parry, D.A., and Weber, K. (2003). In vivo and in vitro evidence that the four essential intermediate filament (IF) proteins A1, A2, A3 and B1 of the nematode Caenorhabditis elegans form an obligate heteropolymeric IF system. J. Mol. Biol. 333, 307-319. Abstract Article

Karabinos, A., Sch_nemann, J., and Weber, K. (2004). Most genes encoding cytoplasmic intermediate filament (IF) proteins of the nematode Caenorhabditis elegans are required in late embryogenesis. Eur. J. Cell Biol. 83, 457-468. Abstract Article

Knust, E., and Bossinger, O. (2002). Composition and formation of intercellular junctions in epithelial cells. Science 298, 1955-1959. Abstract Article

Koppen, M., Simske, J.S., Sims, P.A., Firestein, B.L., Hall, D.H., Radice, A.D., Rongo, C., and Hardin, J.D. (2001). Cooperative regulation of AJM-1 controls junctional integrity in Caenorhabditis elegans epithelia. Nat. Cell Biol. 3, 983-991. Abstract Article

Koppen, M., Simske, J.S., Sims, P.A., Firestein, B.L., Hall, D.H., Radice, A.D., Rongo, C., and Hardin, J.D. (2001). Cooperative regulation of AJM-1 controls junctional integrity in Caenorhabditis elegans epithelia. Nat. Cell Biol. 3, 983-991. Abstract Article

Legouis, R., Gansmuller, A., Sookhareea, S., Bosher, J.M., Baillie, D.L., and Labouesse, M. (2000). LET-413 is a basolateral protein required for the assembly of adherens junctions in Caenorhabditis elegans. Nat. Cell Biol. 2, 415-422. Abstract Article

Legouis, R., Jaulin-Bastard, F., Schott, S., Navarro, C., Borg, J.P., and Labouesse, M. (2003). Basolateral targeting by leucine-rich repeat domains in epithelial cells. EMBO Rep. 4, 1096-1102. Abstract Article

Leung, B., Hermann, G.J., and Priess, J.R. (1999). Organogenesis of the Caenorhabditis elegans intestine. Dev. Biol. 216, 114-134. Abstract Article

McKeown, C., Praitis, V., and Austin, J. (1998). sma-1 encodes a $\beta$ H-spectrin homolog required for Caenorhabditis elegans morphogenesis. Development 125, 2087-2098. Abstract

McMahon, L., Legouis, R., Vonesch, J.L., and Labouesse, M. (2001). Assembly of C. elegans apical junctions involves positioning and compaction by LET-413 and protein aggregation by the MAGUK protein DLG-1. J. Cell Sci. 114, 2265-2277. Abstract

Mishima, M., Kaitna, S., and Glotzer, M. (2002). Central spindle assembly and cytokinesis require a kinesin-like protein/RhoGAP complex with microtubule bundling activity. Dev. Cell 2, 41-54. Abstract Article

Mohler, W.A., Shemer, G., del Campo, J.J., Valansi, C., Opoku-Serebuoh, E., Scranton, V., Assaf, N., White, J.G., and Podbilewicz, B. (2002). The type I membrane protein EFF-1 is essential for developmental cell fusion. Dev. Cell 2, 355-362. Abstract Article

Mohler, W.A., Simske, J.S., Williams-Masson, E.M., Hardin, J.D., and White, J.G. (1998). Dynamics and ultrastructure of developmental cell fusions in the Caenorhabditis elegans hypodermis. Curr. Biol. 8, 1087-1090. Abstract Article

Moorthy, S., Chen, L., and Bennett, V. (2000). Caenorhabditis elegans $\beta$-G spectrin is dispensable for establishment of epithelial polarity, but essential for muscular and neuronal function. J. Cell Biol. 149, 915-930. Abstract Article

Muller, H.A., and Bossinger, O. (2003). Molecular networks controlling epithelial cell polarity in development. Mech. Dev. 120, 1231-1256. Abstract Article

Nance, J., Munro, E.M., and Priess, J.R. (2003). C. elegans PAR-3 and PAR-6 are required for apicobasal asymmetries associated with cell adhesion and gastrulation. Development 130,5339-5350. Abstract Article

Nance, J., and Priess, J.R. (2002). Cell polarity and gastrulation in C. elegans. Development 129, 387-397. Abstract 
Nelson, W.J. (2003). Adaptation of core mechanisms to generate cell polarity. Nature 422, 766-774. Abstract Article

Nievers, M.G., Schaapveld, R.Q., and Sonnenberg, A. (1999). Biology and function of hemidesmosomes. Matrix Biol. 18, 5-17. Abstract Article

Norman, K.R., and Moerman, D.G. (2002). $\gamma$ spectrin is essential for morphogenesis and body wall muscle formation in Caenorhabditis elegans. J. Cell Biol. 157, 665-677. Abstract Article

Pellettieri, J., and Seydoux, G. (2002). Anterior-posterior polarity in C. elegans and Drosophila--PARallels and differences. Science 298, 1946-1950. Abstract Article

Pettitt, J., Cox, E.A., Broadbent, I.D., Flett, A., and Hardin, J. (2003). The Caenorhabditis elegans p120 catenin homologue, JAC-1, modulates cadherin-catenin function during epidermal morphogenesis. J. Cell Biol. 162, 15-22. Abstract Article

Piekny, A.J., Johnson, J.L., Cham, G.D., and Mains, P.E. (2003). The Caenorhabditis elegans nonmuscle myosin genes $n m y-1$ and $n m y-2$ function as redundant components of the let-502/Rho-binding kinase and mel-11/myosin phosphatase pathway during embryonic morphogenesis. Development 130, 5695-5704. Abstract Article

Plenefisch, J.D., Zhu, X., and Hedgecock, E.M. (2000). Fragile skeletal muscle attachments in dystrophic mutants of Caenorhabditis elegans: isolation and characterization of the mua genes. Development 127, 1197-1207. Abstract

Portereiko, M.F., and Mango, S.E. (2001). Early morphogenesis of the Caenorhabditis elegans pharynx. Dev. Biol. 233, 482-494. Abstract Article

Portereiko, M.F., Saam, J., and Mango, S.E. (2004). ZEN-4/MKLP1 is required to polarize the foregut epithelium. Curr. Biol. 14, 932-941. Abstract Article

Priess, J.R., and Hirsh, D.I. (1986). Caenorhabditis elegans morphogenesis: the role of the cytoskeleton in elongation of the embryo. Dev. Biol. 117, 156-173. Abstract Article

Raich, W.B., Agbunag, C., and Hardin, J. (1999). Rapid epithelial-sheet sealing in the Caenorhabditis elegans embryo requires cadherin-dependent filopodial priming. Curr. Biol. 9, 1139-1146. Abstract Article

Raich, W.B., Moran, A.N., Rothman, J.H., and Hardin, J. (1998). Cytokinesis and midzone microtubule organization in Caenorhabditis elegans require the kinesin-like protein ZEN-4. Mol. Biol. Cell 9, 2037-2049. Abstract

Reddien, P.W., and Horvitz, H.R. (2000). CED-2/CrkII and CED-10/Rac control phagocytosis and cell migration in Caenorhabditis elegans. Nat. Cell Biol. 2, 131-136. Abstract Article

Rostaing, P., Weimer, R.M., Jorgensen, E.M., Triller, A., and Bessereau, J.L. (2004). Preservation of immunoreactivity and fine structure of adult C. elegans tissues using high-pressure freezing. J. Histochem. Cytochem. 52, 1-12. Abstract

Sakisaka, T., and Takai, Y. (2004). Biology and pathology of nectins and nectin-like molecules. Curr. Opin. Cell Biol. 16, 513-521. Abstract Article

Sasakura, H., Inada, H., Kuhara. A., Fusaoka, E., Takemoto, D., Takeuchi, K., and Mori, I. (2005). Maintenance of neuronal positions in organized ganglia by SAX-7, a Caenorhabditis elegans homologue of L1. EMBO J. 24, 1477-1488. Abstract Article

Segbert, C., Johnson, K., Theres, C., van Furden, D., and Bossinger, O. (2004). Molecular and functional analysis of apical junction formation in the gut epithelium of Caenorhabditis elegans. Dev. Biol. 266, 17-26. Abstract Article

Shemer, G., Suissa, M., Kolotuev, I., Nguyen, K.C., Hall, D.H., and Podbilewicz, B. (2004). EFF-1 is sufficient to initiate and execute tissue-specific cell fusion in C. elegans. Curr. Biol. 14, 1587-1591. Abstract Article 
Simske, J.S., K_ppen, M., Sims, P., Hodgkin, J., Yonkof, A., and Hardin, J. (2003). The cell junction protein VAB-9 regulates adhesion and epidermal morphology in C. elegans. Nat. Cell Biol. 5, 619-625. Abstract Article

Soto, M.C., Qadota, H., Kasuya, K., Inoue, M., Tsuboi, D., Mello, C.C., and Kaibuchi, K. (2002). The GEX-2 and GEX-3 proteins are required for tissue morphogenesis and cell migrations in C. elegans. Genes Dev. 16, 620-632. Abstract Article

Speck, O., Hughes, S.C., Noren, N.K., Kulikauskas, R.M., and Fehon, R.G. (2003). Moesin functions antagonistically to the Rho pathway to maintain epithelial integrity. Nature 421, 83-87. Abstract Article

Tsukita, S., Furuse, M., and Itoh, M. (1999). Structural and signalling molecules come together at tight junctions. Current Opinion in Cell Biology 11, 628-633. Abstract Article

Van Furden, D., Johnson, K., Segbert, C., and Bossinger, O. (2004). The C. elegans ezrin-radixin-moesin protein ERM-1 is necessary for apical junction remodelling and tubulogenesis in the intestine. Dev. Biol. 272, 262-276. Abstract Article

Van Furden, D., Johnson, K., Segbert, C., and Bossinger, O. (2004). The C. elegans ezrin-radixin-moesin protein ERM-1 is necessary for apical junction remodelling and tubulogenesis in the intestine. Dev. Biol. 272, 262-276. Abstract Article

Vasioukhin, V., Bauer, C., Yin, M., and Fuchs, E. (2000). Directed actin polymerization is the driving force for epithelial cell-cell adhesion. Cell 100, 209-219. Abstract Article

Volk, T. (1999). Singling out Drosophila tendon cells: a dialogue between two distinct cell types. Trends Genet. 15, 448-453. Abstract Article

Wang, X., Kweon, J., Larson, S., and Chen, L. (2005). A role for the C. elegans L1CAM homologue lad-1/sax-7 in maintaining tissue attachment. Dev. Biol. 284, 273-291. Abstract

Wissmann, A., Ingles, J., and Mains, P.E. (1999). The Caenorhabditis elegans mel-11 myosin phosphatase regulatory subunit affects tissue contraction in the somatic gonad and the embryonic epidermis and genetically interacts with the Rac signaling pathway. Dev. Biol. 209, 111-127. Abstract Article

Wissmann, A., Ingles, J., McGhee, J.D., and Mains, P.E. (1997). Caenorhabditis elegans LET-502 is related to Rho-binding kinases and human myotonic dystrophy kinase and interacts genetically with a homolog of the regulatory subunit of smooth muscle myosin phosphatase to affect cell shape. Genes Dev. 11, 409-422. Abstract

Woo, W.M., Goncharov, A., Jin, Y., and Chisholm, A.D. (2004). Intermediate filaments are required for C. elegans epidermal elongation. Dev. Biol. 267, 216-229. Abstract Article

Zegers, M.M., O'Brien, L.E., Yu, W., Datta, A., and Mostov, K.E. (2003). Epithelial polarity and tubulogenesis in vitro. Trends Cell Biol. 13, 169-176. Abstract Article

All WormBook content, except where otherwise noted, is licensed under a Creative Commons Attribution License 